\title{
Toward high production of graphene flakes - A review on recent developments in their synthesis methods and scalability
}

Muhammad Izhar Kairi ${ }^{\mathrm{a}}$, Sebastian Dayou ${ }^{\mathrm{b}}$, Nurul Izni Kairic, Suriani Abu Bakar ${ }^{\mathrm{d}}$, Brigitte Vigolo ${ }^{\mathrm{e}^{*}}$, Abdul Rahman Mohamed ${ }^{\mathrm{a}^{*}}$

${ }^{a}$ School of Chemical Engineering, Engineering Campus, Universiti Sains Malaysia, 14300 Nibong Tebal, Seberang Perai Selatan, Pulau Pinang, Malaysia

${ }^{\mathrm{b}}$ School of Engineering and Technology, University College of Technology Sarawak, 868 Persiaran Brooke, 96000 Sibu, Sarawak, Malaysia

${ }^{\mathrm{c}}$ Centre for Foundation Studies, Universiti Teknologi Petronas, 32610 Seri Iskandar, Perak, Malaysia

${ }^{\mathrm{d}}$ Nanotechnology Research Centre, Faculty of Science and Mathematics, Universiti Pendidikan Sultan Idris, 35900 Tanjung Malim, Perak, Malaysia

e Institut Jean Lamour, CNRS-Université de Lorraine, BP 70239, 54506 Vandceuvrelés-Nancy, France

*Corresponding authors. 
E-mail: Brigitte.Vigolo@univ-lorraine.fr (B. Vigolo)

E-mail: chrahman@usm.my (A.R. Mohamed)

\section{Abstract}

Research and development in graphene synthesis have been rapidly growing the past few years because of their extraordinary physical, mechanical, thermal, electrical and optical properties. Graphene flakes, one of the most popular form of graphene, can be used for many applications such as conductive inks, nanofluids, supercapacitors, composites etc. Synthesis of graphene flakes is indeed in the path to reach the largescale production even if cost of production and efficiency are required to be further improved. This review sheds light on the recent advancements of graphene flake synthesis and it gives a comprehensive analysis of the synthesis methods. Keys for further improvements are proposed based on the mechanisms involved in the graphene flake formation.

Keywords: Graphene flakes; synthesis; ball-milling; electrochemical exfoliation; shearing; explosion 


\section{Contents}

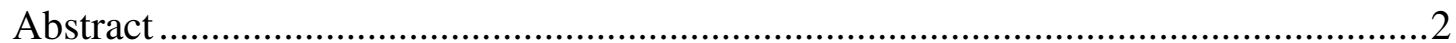

Contents

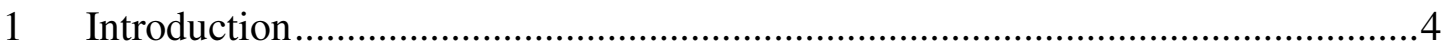

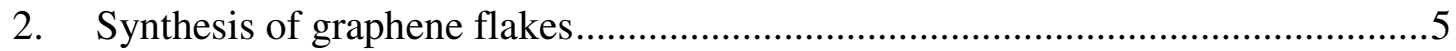

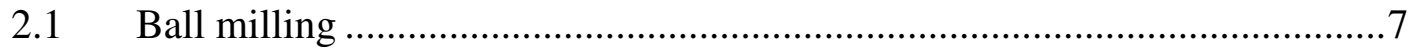

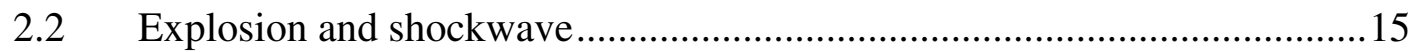

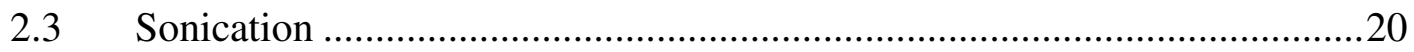

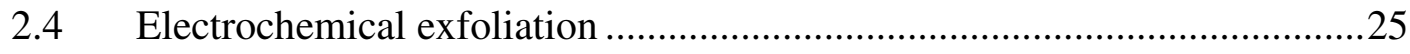

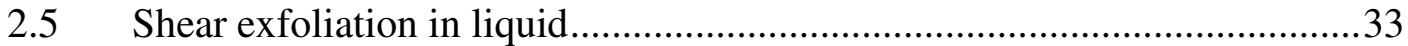

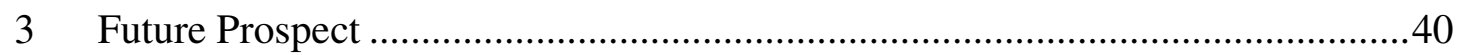

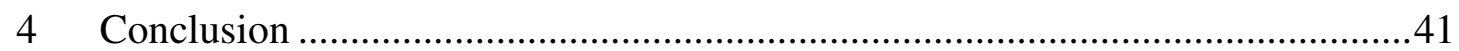

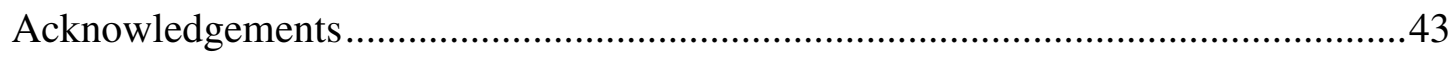

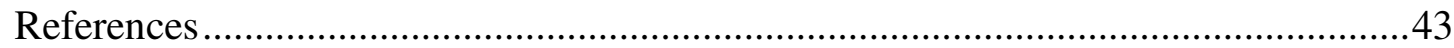




\section{$1 \quad$ Introduction}

The introduction of new materials has enabled the growth of new technologies that have a beneficial impact on society. Currently, we are in the precipice of a new age of 2-dimensional (2D) materials. Boron nitride (BN) ${ }^{1-3}$, bismuth telluride $\left(\mathrm{Bi}_{2} \mathrm{Te}_{3}\right)^{4,5}$, bismuth (III) selenide $\left(\mathrm{Bi}_{2} \mathrm{Se}_{3}\right)^{6}$, molybdenum disulfide $\left(\mathrm{MoS}_{2}\right)^{7,8}$, molybdenum diselenide $\left(\mathrm{MoSe}_{2}\right)^{9,10}$, molybdenum ditelluride $\left(\mathrm{MoTe}_{2}\right)^{11}$, tungsten disulfide $\left(\mathrm{WS}_{2}\right)$ ${ }^{12}$, tungsten diselenide $\left(\mathrm{WSe}_{2}\right)^{13,14}$, silicone ${ }^{15,16}$, phosphorene ${ }^{17,18}$, bismuthene ${ }^{19}$, graphyne ${ }^{20,21}$, graphane ${ }^{22}$ and graphene ${ }^{23,24}$ are among the 2D materials that have been investigated. Within that group, graphene is the most-researched material since its discovery in $2004^{25,26}$. It is investigated for use in the next generation devices due to its outstanding combination of properties not observed in any other type of materials. Its magnificent properties are attributed to the strong bonding between the hexagonal arrangements of carbon atoms that make up graphene.

Graphene can be produced in several forms including flakes ${ }^{27-29}$, ribbons ${ }^{30,31}$, and large-area sheets ${ }^{32,33}$. They differ in lateral dimensions; flakes with limited lateral dimension (from several nanometers to micrometers), large-area sheets possess macroscopic and extended lateral dimensions, while ribbons have one lateral dimension that is at least one order of magnitude larger than the others ${ }^{34}$. These differences allow graphene to be used in various types of applications. For example, large-area graphene sheets are more suited for wafer-scale thin film-like applications such as transparent conductive electrode ${ }^{35}$, while graphene flakes (GFs) are investigated for conductive ink applications ${ }^{36,37}$. This review focuses on the various synthesis methods of GFs. This form of graphene is also sometimes referred to as graphene nanosheets ${ }^{38-44}$, graphene microsheets ${ }^{45}$, graphene platelet (or nanoplatelet) ${ }^{46,47}$ graphene powder ${ }^{48,49}$ or graphene quantum dots ${ }^{50,51}$ by other researchers. Until today, the review work on 
GFs seldom reports several kinds of methods and heavily emphasizes on the route of chemical methods such as pre-oxidization via Hummers' method or modified Hummers' method before exfoliation. However, it is often ignored that several developed physical methods are able to produce large volume of GFs of good quality that would be able to meet various applications that demands greater quality than that produced by the chemical methods. Indeed, graphene oxide $(\mathrm{GO})$ and reduced graphene oxide ( $\mathrm{rGO}$ ) produced by these chemical methods are highly defected and they can be considered of a different class of graphene with their own advantages. In this review paper, GF synthesis from graphite by these alternative methods including ball-milling, sonication, shock waves, shearing in liquid and electrochemical method are analyzed and discussed. The review is organized in three main parts. The first part deals with compilation of the various methods of GF synthesis along with the basic mechanisms of the processes. The second part analyzes the advantages, disadvantages and potentials of these synthesis methods for scaling-up. Lastly, some future prospects of the covered methods are given.

\section{Synthesis of graphene flakes}

Currently, exfoliation of graphite into GF synthesis mostly involves chemical oxidation of graphite to graphite oxide, followed by exfoliation to GO and then reduction to $\mathrm{rGO}$ in the presence of chemical reductants such as octadecyl amine ${ }^{52}$, phenyl isocyanates ${ }^{53}$, hydrazine ${ }^{54}$, polymers ${ }^{55}$ and pyrene derivatives ${ }^{56}$. GO and rGO are easily dispersed in various solvents which is beneficial for its processing for diverse applications such as in the formulation of water-based nanofluids for heat transfer usage ${ }^{57}$, while GFs are difficult to be dispersed due to their hydrophobicity. Graphite oxide can be prepared by using Brodie's method ${ }^{58}$, Hummers' method ${ }^{59}$ or modified 
Hummers' method ${ }^{60}$; the latter two methods are the most prevalent. These techniques are, however, harmful since they involve the oxidative treatment of graphite by potassium permanganate $\left(\mathrm{KMnO}_{4}\right)$ and sodium nitrate $\left(\mathrm{NaNO}_{3}\right)$ in concentrated $\mathrm{H}_{2} \mathrm{SO}_{4}$. Such mixture and other related procedures would generate toxic gases in the form of nitrogen dioxide $\left(\mathrm{NO}_{2}\right)$ or dinitrogen tetroxide $\left(\mathrm{N}_{2} \mathrm{O}_{4}\right)$.

Unlike graphene, rGO, prepared by reduction of GO, does not have the perfect graphene structure defined in the International Union of Pure and Applied Chemistry (IUPAC), which describes graphene as a "single carbon layer of graphite structure, describing its nature by analogy of a polycyclic aromatic hydrocarbon of quasi-infinite size" ${ }^{61}$. Bianco et al. ${ }^{34}$ recommended that $\mathrm{rGO}$ nomenclature to be "graphene oxide that has been reductively processed by chemical, thermal, microwave, photo-chemical, photo-thermal or microbial/bacteria methods to reduce its oxygen content". Even after a comprehensive reduction process, it is practically impossible to remove all of the oxygen functional groups on the rGO surfaces. This puts them in a different class than that of graphene ${ }^{62}$ and the reason why the term rGO is used instead of graphene. The presence of oxygen functional groups is responsible for its hydrophilic behavior but it would also disrupt the electronic properties of the rGO, dramatically reducing that way its physical properties. Raman $\mathrm{D} / \mathrm{G}$ intensity ratio $\left(\mathrm{I}_{\mathrm{D}} / \mathrm{I}_{\mathrm{G}}\right)$ is usually used to measure the extent of defects in graphene structure. $\mathrm{I}_{\mathrm{D}} / \mathrm{I}_{\mathrm{G}}$ of $\mathrm{GO}$ and $\mathrm{rGO}$ normally gives a high value of between 1.0 to $2.0^{38,63-65}$. Even so, it has been proven that GO and rGO were found to be very useful in catalysis and composites ${ }^{66}$. However, other applications especially when high performance is required, such as in energy storage and generation devices ${ }^{67}$ would demand a higher structural quality of graphene.

This review is focused on top-down methods, which have greater potential for production scale-up as opposed to the bottom-up chemical vapor deposition (CVD) 
technique. Previous reports show that the CVD methods were successfully utilized to synthesize GFs ${ }^{68-71}$ using metal catalyst in the form of particles. CVD requires the use of expensive transition metal catalysts with comprehensive experimental setups that often involve flammable gases such as methane and acetylene. In order to grow graphene, significantly high temperature ranging from 600 to $1000{ }^{\circ} \mathrm{C}$ is required and often involves slow ramping and cooling process. Since metal catalyst has to be removed via a dissolution-filtration-drying processes before incorporation of graphene into application ${ }^{72}$, it makes the whole process more costly, complicated and timeconsuming. Nevertheless, CVD can produce better structural quality of graphene compared to its top-down counterpart, and their properties were found to be close to the pristine structure of graphene ${ }^{39,73,74}$. Most large area graphene sheets were synthesized via CVD because of the demand for very high structural quality for their application ${ }^{32,75,76}$. However, the quantity and production cost take precedence for GF applications, which CVD cannot provide. In contrast to CVD, top-down method offers lower cost but at the expense of quality, though still superior than GO and rGO. The next few parts will shine some light on the reported alternative techniques for largescale GF synthesis.

\subsection{Ball milling}

Ball milling is a common method in powder production industry known for its high production capacity and shear crushing force which is very well suited for exfoliation of graphite to produce GFs. Ball milling technique involves breaking down graphitic microstructures into GFs via impact and attrition of metal balls striking the graphitic microstructures in a rotating hollow cylindrical shell. The rotation of the cylindrical shells creates a centrifugal force that will carry the grinding media such as 
zirconia balls in a turbulent and random manner so that the impact can transpire with greater effect. It works on the principle of particle size reduction in line with the top down route for GF synthesis. Generally, milling of graphite can be implemented in either a dry or a wet state. Dry milling can achieve high yield of single layer GF but the use of an argon glove box is a downside, which makes the process more complicated. The average size of the GFs being produced depends heavily on the milling parameters, which include ball-to-graphite ratio, initial weight of graphite, milling duration and milling revolution per minute (rpm). Table 1 shows, in details, some examples of GF synthesis conditions via dry milling and the characteristics of the produced GFs.

In dry milling, milling agent are normally added alongside metal balls to reduce the stress induced in the graphitic structures ${ }^{77,78}$. Alinejad and Mahmoodi ${ }^{79}$ used $\mathrm{NaCl}$ salt as a miller alongside zirconia balls with the ball-mill operated at $350 \mathrm{rpm}$ for 2 hours under $0.4 \mathrm{MPa}$ of argon atmosphere. The addition of $\mathrm{NaCl}$ particles which are substantially brittle and harder than graphite permits graphene nanoflakes of about 50 x $200 \mathrm{~nm}^{2}$ to be attained. The salt particles assist the shear stress mechanism of the zirconia balls and prevent GFs from agglomeration. Furthermore, they can be washed away easily with water after the milling process. In another work, Lv et al. ${ }^{49}$ used $\mathrm{Na}_{2} \mathrm{SO}_{4}$ salt to produce graphene nanosheets in the size range of hundreds square nanometers with a ripple-like corrugations as shown in Fig. 1. Through mechanical peeling and post-milling washing, GF was harvested at a low cost and have the potential to be scaled-up. The authors also claimed that the number of layers in the produced GFs can be controlled from two to tens of layers by merely changing the graphite to $\mathrm{Na}_{2} \mathrm{SO}_{4}$ ratio. In other works, melamine (2,4,6-triamine-1,3,5-triazine) ${ }^{80}$ and ammonia borane $\left(\mathrm{NH}_{3} \mathrm{BH}_{3}\right)^{81}$ were investigated for their role in a dry ball-milling process. Herein, melamine and $\mathrm{NH}_{3} \mathrm{BH}_{3}$ did not act as a miller but instead were used to weaken the van 
der Waals bonding between the graphite layers, which promote easy exfoliation of graphite to produce GFs during the milling process.

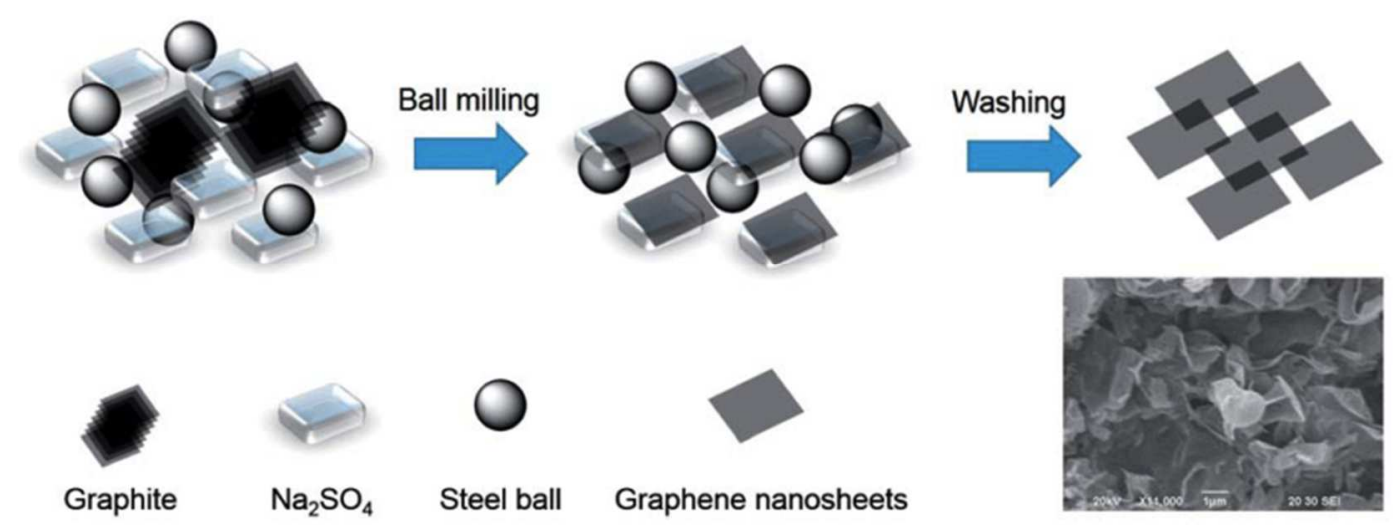

Fig. 1 Schematic of the soluble salt-assisted $\left(\mathrm{Na}_{2} \mathrm{SO}_{4}\right)$ wet ball-mill route to graphene nanosheet powder. The inset is the SEM image of the produced GFs. Reprinted with permission from ${ }^{49}$.

It has been demonstrated in the past that stress reduction in the graphitic materials can be achieved by wet millings. Table 2 lists some of the examples of GF synthesis via wet milling. Knieke et al. ${ }^{82}$ and Yao et al. ${ }^{41}$ successfully produced GFs from graphite powder in a wet milling process, i.e. in an anionic surfactant, sodium dodecyl sulfate (SDS). However, the drawback of using SDS is that it can absorbed on the surface of GF and hard to be removed. This is the reason why other solvents such as N,N-dimethylformamide (DMF) ${ }^{83}$, naphthol polyoxyethylene ether (NPE) ${ }^{84}$, oxalic acid $\left(\mathrm{C}_{2} \mathrm{H}_{2} \mathrm{O}_{4}\right){ }^{85}$ and 1-pyrenecarboxylic acid (1-PCA) ${ }^{86}$ were also considered. Deng et al. ${ }^{87}$ prepared surfactant-free few layer GFs by wet ball milling of graphite in $\mathrm{N}$ methylpyrrolidone (NMP). GF production enhancement was observed according to the power law, but it was only achieved after continuous milling for 10 hours. 
Kim et al. ${ }^{88}$ used wet-milling via a planetary ball-mill to produced GFs which were then used for nanofluid application. It was found that $600 \mathrm{rpm}$ of the planetary ball-mill yielded to larger particle size GFs $(757.5 \mathrm{~nm})$ than $200 \mathrm{rpm}(328 \mathrm{~nm})$. The authors attributed this occurrence to the weight of the zirconia balls and excessive centrifugal forces that eventually disrupted the collision interactions between the metal balls and the starting material. GFs of smaller size show higher surface area and they are more efficient in heat transfer. Besides, low speed ball-milling can minimize intense shock stress that can damage the graphite in-plane crystal; the shear stress being the dominant force in the process. The exfoliation and fracture of the graphite particles were generally caused by shear and compression forces generated from the motion of the balls. Compression forces are predominant at the beginning as the size of graphite is large whereas the shear force can cleave graphite from their outer surfaces as the lateral size of the GFs gets smaller and the van der Waals forces have weakened. It is important to avoid excessive compression forces so as not to damage the crystallinity of graphene. To minimize damages on the GFs, shear-force dominated mechanism need to be ensured and this is the reason why low milling speed was practiced. This, however, increases the processing time.

In contrast to dry milling, wet milling does not require the presence of protecting gas to minimize GFs oxidation but demand an additional purification step to remove the used exfoliants and solvents after the completion of milling process. Occasionally, due to intensive reactions between the solution and the graphitic materials along with the milling forces, it can cause further contamination to the resulting graphene. It seems that both routes have their pros and cons but in terms of scale, quality and volume of produced GFs, dry milling does tick all the boxes. Overall, ball-milling technique has some advantages: production of high quality GFs, it is highly scalable and the size of 
GFs can be varied by a simple modification of the milling parameters, but most often this method involves long processing cycles that reduces the yield rate of GF production. 
Table 1 Examples of GFs synthesis via dry milling and their characteristics.

\begin{tabular}{|c|c|c|c|c|c|}
\hline \multicolumn{3}{|c|}{ Dry milling conditions } & \multirow{2}{*}{$\begin{array}{l}\text { Characteristics of produced } \\
\text { graphene }\end{array}$} & \multirow[t]{2}{*}{ Remarks } & \multirow[t]{2}{*}{ References } \\
\hline Setup & Milling agent & $\begin{array}{l}\text { Speed, duration, } \\
\text { environment }\end{array}$ & & & \\
\hline \multirow[t]{2}{*}{$\begin{array}{l}\text { Planetary ball-mill } \\
\text { Zirconia ball }\end{array}$} & $\mathrm{NaCl}$ & $\begin{array}{l}350 \mathrm{rpm} \\
2 \text { hours } \\
0.4 \mathrm{MPa} \text { of } \mathrm{Ar}\end{array}$ & $\begin{array}{l}\text { Multilayer GF } \\
\text { Size }=50 \times 200 \mathrm{~nm}^{2}\end{array}$ & $\begin{array}{l}\text { Use } \mathrm{NaCl} \text { as miller which } \\
\text { could be washed away easily } \\
\text { after milling }\end{array}$ & 79 \\
\hline & Melamine $\left(\mathrm{Na}_{2} \mathrm{SO}_{4}\right)$ & $\begin{array}{l}100 \mathrm{rpm} \\
30 \mathrm{~min} \\
\text { Air }\end{array}$ & $\begin{array}{l}\mathrm{I}_{\mathrm{G}} / \mathrm{I}_{\mathrm{D}}=\sim 2.4 \\
L_{\mathrm{a}}=\sim 40 \mathrm{~nm}\end{array}$ & $\begin{array}{l}\text { Melamine disappeared upon } \\
\text { washing with hot water }\end{array}$ & 80 \\
\hline Stainless steel jar mill & Melamine & $\begin{array}{l}150 \mathrm{rpm} \\
24 \text { hours }\end{array}$ & $\begin{array}{l}\text { Graphene nanosheets with } \\
\text { size in the range of hundreds } \\
\text { square nanometers } \\
\mathrm{I}_{\mathrm{D}} / \mathrm{I}_{\mathrm{G}}=0.507 \text { (for } 200: 1 \text { of } \\
\text { miller to graphite weight } \\
\text { ratio) }\end{array}$ & $\begin{array}{l}\mathrm{Use} \mathrm{Na}_{2} \mathrm{SO}_{4} \text { as miller which } \\
\text { can be washed away easily } \\
\text { after milling. XPS showed } \\
\text { that GFs were not deeply } \\
\text { oxidized during ball-milling. }\end{array}$ & 49 \\
\hline Planetary mill & $\begin{array}{l}\text { Ammonia Borane } \\
\left(\mathrm{NH}_{3} \mathrm{BH}_{3}\right)\end{array}$ & $\begin{array}{l}150 \mathrm{rpm} \\
4 \text { hours }\end{array}$ & $\begin{array}{l}\text { Single or few-layer GF } \\
<6 \text { layers } \\
\mathrm{I}_{\mathrm{D}} / \mathrm{I}_{\mathrm{G}}<0.5\end{array}$ & $\begin{array}{l}\text { Ammonia borane could be } \\
\text { removed using ethanol. }\end{array}$ & 81 \\
\hline $\begin{array}{l}\text { Planetary ball-mill } \\
\text { Stainless steel ball }\end{array}$ & $\begin{array}{l}\text { Milling agent }=\text { Dry ice } \\
(\mathrm{KOH})\end{array}$ & $\begin{array}{l}500 \mathrm{rpm} \\
48 \text { hours }\end{array}$ & $\begin{array}{l}\text { Edge carboxylated graphite } \\
\mathrm{I}_{\mathrm{D}} / \mathrm{I}_{\mathrm{G}}=1.16\end{array}$ & $\begin{array}{l}\text { End product was graphite. } \\
\text { Purification required Soxhlet } \\
\text { extraction with } 1 \mathrm{M} \mathrm{HCl} \text { to } \\
\text { completely acidify } \\
\text { carboxylates and to remove } \\
\text { metallic impurities. }\end{array}$ & 40 \\
\hline
\end{tabular}


Table 2 Examples of GFs synthesis via wet milling and their characteristics.

\begin{tabular}{|c|c|c|c|c|c|}
\hline $\begin{array}{l}\text { Equipment, ball type, } \\
\text { ball size }\end{array}$ & Surfactant/solvent & Speed, duration & Graphene characteristics & Remarks & References \\
\hline $\begin{array}{l}\text { Ceramic grinding chamber } \\
\text { Yttria zirconia ball } \\
50 \& 100 \mu \mathrm{m}\end{array}$ & $\begin{array}{l}\text { Sodium dodecyl sulfate } \\
\text { (SDS) }\end{array}$ & $\begin{array}{l}233-2100 \mathrm{rpm} \\
3 \text { hours }\end{array}$ & $\begin{array}{l}\text { Mono- and multilayer } \\
25 \mathrm{~g} / \mathrm{L} \text { produced } \\
\mathrm{I}_{\mathrm{D}} / \mathrm{I}_{\mathrm{G}}=\sim 0.6\end{array}$ & & 82 \\
\hline $\begin{array}{l}\text { Zirconia ball } \\
2 \mathrm{~mm}\end{array}$ & SDS & $\begin{array}{l}100 \mathrm{rpm} \\
12 \text { hours }\end{array}$ & $\begin{array}{l}\text { Monolayer and few-layer } \\
\mathrm{I}_{\mathrm{D}} / \mathrm{I}_{\mathrm{G}}<0.05\end{array}$ & $\begin{array}{l}\text { Wet-milling was } \\
\text { subsequently followed by } \\
\text { sonication for } 2 \text { hours with } \\
80 \mathrm{~W} \text { power output }\end{array}$ & 41 \\
\hline Milling container & $\begin{array}{l}\text { N-methylpyrrolidone } \\
\text { (NMP) }\end{array}$ & $\begin{array}{l}500 \mathrm{rpm} \\
10 \text { hours }\end{array}$ & $\begin{array}{l}\text { Multilayer } \\
\text { Production rate }=0.0085 \\
\mathrm{mg} / \mathrm{mLh} \\
\mathrm{I}_{\mathrm{D}} / \mathrm{I}_{\mathrm{G}}=\sim 0.24\end{array}$ & $\begin{array}{l}\text { Wet milling in } \mathrm{N}- \\
\text { methylpyrrolidone }\end{array}$ & 87 \\
\hline \multirow[t]{2}{*}{$\begin{array}{l}\text { Planetary ball-mill } \\
\text { Zirconia ball } \\
1 \mathrm{~mm}\end{array}$} & Distilled water & $\begin{array}{l}200 \mathrm{rpm} \\
1 \text { hour }\end{array}$ & $\begin{array}{l}\text { GF particle size }=328 \mathrm{~nm} \\
\lambda=680 \mathrm{~mW} / \mathrm{mK}\end{array}$ & $\begin{array}{l}\text { The GF produced were } \\
\text { used in nanofluids based } \\
\text { on distilled water. }\end{array}$ & 88 \\
\hline & $\begin{array}{l}\mathrm{N}, \mathrm{N} \text {-dimethylformamide } \\
(\mathrm{DMF})\end{array}$ & $\begin{array}{l}300 \mathrm{rpm} \\
30 \text { hours }\end{array}$ & $\begin{array}{l}\text { Single- and few-layer GF } \\
<4 \text { layers } \\
\mathrm{I}_{\mathrm{D}} / \mathrm{I}_{\mathrm{G}}=\sim 0.34\end{array}$ & $\begin{array}{l}\text { DMF was a toxic solvent } \\
\text { with a high boiling point } \\
\text { of } 153^{\circ} \mathrm{C} \text {. }\end{array}$ & 89 \\
\hline Tungsten carbide jar & Methanol & $\begin{array}{l}300 \mathrm{rpm} \\
30 \text { hours }\end{array}$ & $\begin{array}{l}\text { Few layer graphene } \\
I_{D} / I_{G}=0.37-0.38 \\
\text { Electrical conductivity }= \\
6700 \mathrm{~S} / \mathrm{m}\end{array}$ & $\begin{array}{l}\text { 1-pyrenecarboxylic acid } \\
\left(\mathrm{C}_{17} \mathrm{H}_{10} \mathrm{O}_{2}\right) \text { was used as } \\
\text { exfoliant }\end{array}$ & 86 \\
\hline
\end{tabular}


Stainless steel pot

Stainless steel ball

$500 \mathrm{rpm}$

12 hours
Chemically functional

trilayer and few layer

graphene

$\mathrm{I}_{\mathrm{D}} / \mathrm{I}_{\mathrm{G}}=0.025$ (after heat

treatment)
Oxalic acid $\left(\mathrm{C}_{2} \mathrm{H}_{2} \mathrm{O}_{4}\right)$ was

used as milling agent. 


\subsection{Explosion and shockwave}

In the past, fullerene and carbon nanotubes were obtained by exploding graphite, iron and nickel wires in organic solvents ${ }^{90-92}$. Unlike other methods, explosion-driven GF synthesis has a very short lead time. The explosion provided sufficient energy injection to exfoliate graphite, which then reacted with the metal catalysts. However, it is a very delicate process whereby excessive energy injection would damage the graphene crystallinity, similar effects were observed in the case of excessive compression force in ball-milling of graphite ${ }^{87}$.

Graphene synthesis via detonation was first discovered by Nepal et al. ${ }^{93}$ who produced gram scale graphene nanosheets via controlled detonation of acetylene $\left(\mathrm{C}_{2} \mathrm{H}_{2}\right)$ in the presence of $\mathrm{O}_{2}$. The experimental setup being utilized was the same for normal carbonaceous soot synthesis. However, the peak detonation temperature was roughly twice $(4000 \mathrm{~K})$ the combustion temperature for soot production. As a result, most hydrogen was removed from the main chamber leaving just pure carbon with graphenelike characteristics. The presence of GFs after detonation-driven synthesis was verified by Raman spectroscopy and it was found that the best structural quality of GFs can be obtained at high $\mathrm{O}_{2}$ to $\mathrm{C}_{2} \mathrm{H}_{2}$ ratio. The authors suggested that during the detonation, which only lasted about $15 \mathrm{~ms}$, the hydrocarbon was first converted into free carbon atoms and ions. The chamber was then allowed to cool to $300 \mathrm{~K}$ at which the carbon atoms and ions condensed into carbon nanoparticles that quickly aggregated into GFs. Most of the hydrogen from acetylene was removed from the chamber together with oxygen. Otherwise, carbonaceous soot has been found within the chamber.

Gao et al. ${ }^{94}$ managed to produced mono- and few-layer GFs via explosion generated by electric wire explosion charge voltage on high-purity graphite stick in distilled water at ambient temperature. During that short burst of energy carried by the 
explosion, the graphite was exfoliated and broken into smaller pieces of GFs. Schematic diagram in Fig. 2 illustrates the mechanism of the explosion process for graphene synthesis. The energy injection or explosion needs to be powerful enough to overcome the van der Waals forces but not too powerful that it could completely disrupt the fundamental crystallinity of graphene. In this case, less than 10 layers of graphene can be obtained within the charging voltage of $21-25 \mathrm{kV}$ and the optimal value to get monolayer graphene was found to be around 22.5 to $23.5 \mathrm{kV}$.

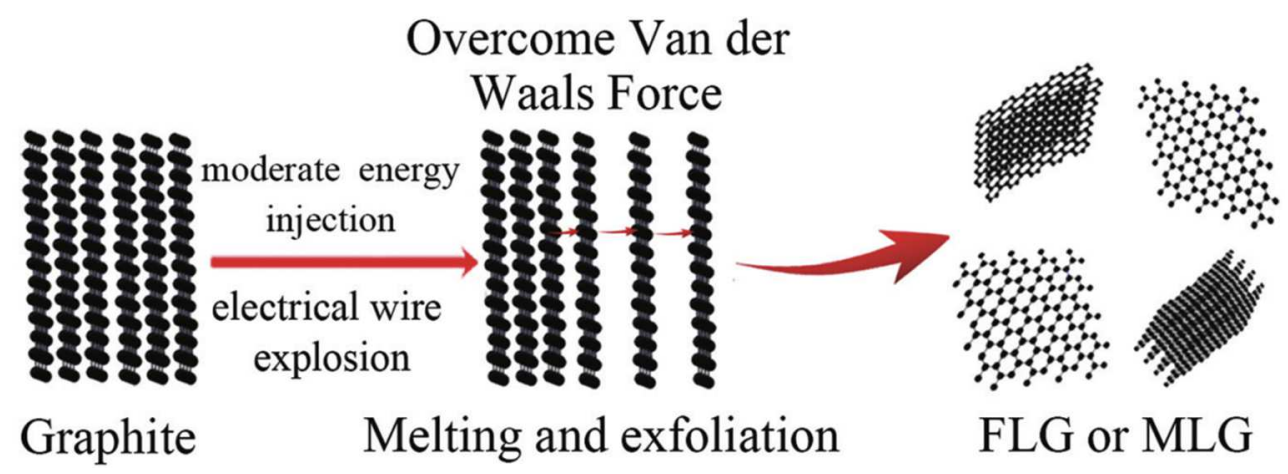

Fig. 2 Illustration of the proposed mechanism for the formation of graphene nanosheets in electrical explosion of graphite sticks. Reprinted with permission from ${ }^{94}$.

Meanwhile, Yin et al. ${ }^{95}$ took a different approach. They synthesized GFs via a one-step shockwave-driven treatment. Instead of just breaking graphite into smaller pieces of GFs, herein, three compounds in the form of calcium carbonate $\left(\mathrm{CaCO}_{3}\right)$, magnesium $(\mathrm{Mg})$ and ammonium nitrate $\left(\mathrm{NH}_{4} \mathrm{NO}_{3}\right)$ were used concurrently as the carbon source, reductant and nitrogen-doping source, respectively. Nitromethane $\left(\mathrm{CH}_{3} \mathrm{NO}_{2}\right)$ was used as the main charge to thrust steel flyer to a high velocity (1 to 3 $\mathrm{km} / \mathrm{s}$ ) within the stainless steel sample container. The subsequent explosion initiated extremely rapid shock-induced decomposition and chemical reaction that convert carbonate into multilayer graphene and nitrogen-doped graphene as shown in eq. (1) to 
(3) and Fig. 3. The same template was then used to synthesize few-layer graphene (FLG) sheets from dry ice (solid $\mathrm{CO}_{2}$ ) with calcium hydride $\left(\mathrm{CaH}_{2}\right)$ and $\mathrm{NH}_{4} \mathrm{NO}_{3}{ }^{96}$. In this work, an electronic detonator was utilized with the main charge being cyclotrimethylenetrinitramine or $\mathrm{RDX}\left(\mathrm{C}_{3} \mathrm{H}_{6} \mathrm{~N}_{6} \mathrm{O}_{6}\right)$, which initiated the shockwave. The whole operation per process cycle was tightly controlled to be completed within $90 \mathrm{~s}$. The shockwave explosion normally lasted for a very short duration of around $10^{-}$ ${ }^{6} \mathrm{~s}$. The rest of the lead time was to give time for the recovered container to settle down before it is safe to be opened to remove the sample.

$$
\begin{aligned}
& \mathrm{CaCO}_{3} \rightarrow \mathrm{CO}_{2}+\mathrm{CaO} \\
& 2 \mathrm{Mg}+\mathrm{CO}_{2} \rightarrow \mathrm{C} \bullet+2 \mathrm{MgO} \\
& \mathrm{C} \bullet \rightarrow \text { graphene }
\end{aligned}
$$

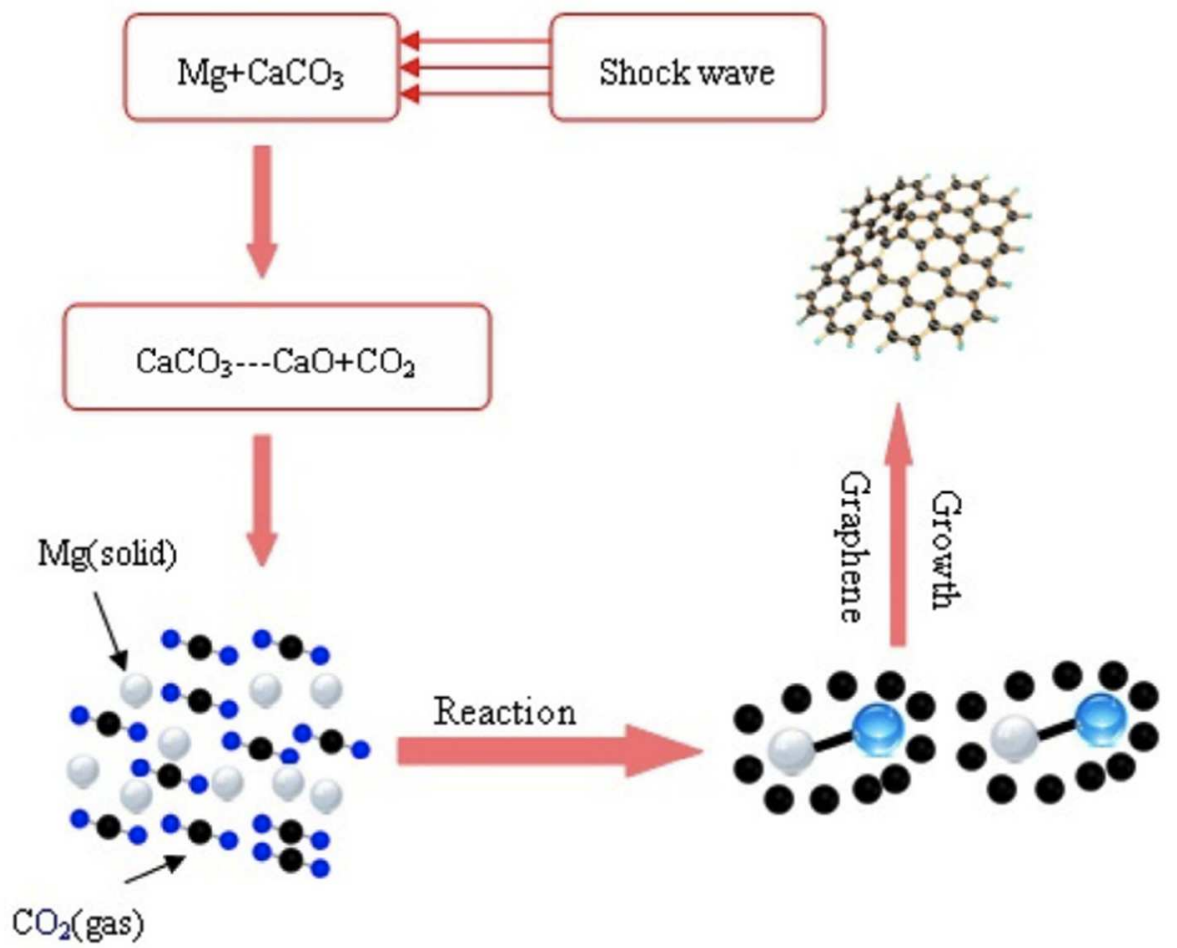

Fig. 3 Illustration of the proposed mechanism for shockwave-induced synthesis of graphene from carbonate. Reprinted with permission from ${ }^{95}$. 
Table 3 compiles the works related to explosion and shock-wave exfoliation that have been described earlier. The main advantage of these methods is the significantly short processing time and thus they produce GFs at a high yield rate. However, they are quite dangerous and require strict safety precautions when executing experimental works. This is probably the reason why the number of research groups undertaking these methods for GF synthesis are considerably low but more study would be possible if a clear standard consideration of safety and the detailed procedure in the operation process involved are available. These methods generally operated in a very delicate manner and they require precise control of the reaction conditions since the system is quite sensitive to even a small change in processing parameters that can give enormous effects to the quality of GFs produced. This attested the complexity of the process, which may be due to its infancy for GF synthesis, but it might be the answer to mass-produced GFs in the future. More works are needed to be done in a more systematic approach to refine the current explosion-driven methods by optimizing the reaction conditions for GF synthesis. 
Table 3 Examples of GFs synthesis via explosion and shock-wave and the characteristics of produced graphene.

\begin{tabular}{|c|c|c|c|c|c|}
\hline \multicolumn{3}{|c|}{ Explosion or shock-wave conditions } & \multirow{2}{*}{$\begin{array}{l}\text { Characteristics of } \\
\text { produced graphene }\end{array}$} & \multirow[t]{2}{*}{ Remarks } & \multirow[t]{2}{*}{ References } \\
\hline Equipment, main charge & $\begin{array}{l}\text { Carbon source, reductant, } \\
\text { nitrogen source }\end{array}$ & Explosion conditions & & & \\
\hline $\begin{array}{l}\text { Cylindrical aluminium } \\
\text { chamber }\end{array}$ & Acetylene $\left(\mathrm{C}_{2} \mathrm{H}_{2}\right)$ & $\begin{array}{l}\text { Peak detonation temp. }= \\
4000 \mathrm{~K} \\
\text { Peak detonation pressure }= \\
\sim 13.3 \mathrm{~atm} \\
\mathrm{t}_{\text {Detonation }}=\sim 15 \mathrm{~ms}\end{array}$ & $\begin{array}{l}\text { Mono- to tri-layers } \\
\text { Size }=35-250 \mathrm{~nm} \\
\mathrm{I}_{\mathrm{D}} / \mathrm{I}_{\mathrm{G}}=\sim 0.28-1.33 \\
\text { Specific surface area }=23- \\
187 \mathrm{~m}^{2} / \mathrm{g}\end{array}$ & $\begin{array}{l}\text { Detonator = Spark } \\
\text { generator ignition system } \\
\text { Production rate }=300 \mathrm{~g} / \mathrm{h}\end{array}$ & 93 \\
\hline $\begin{array}{l}\text { Cylindrical stainless steel } \\
\text { explosion chamber }\end{array}$ & Graphite stick & $\begin{array}{l}\text { Optimal charging voltage }= \\
22.5-23.5 \mathrm{kV}\end{array}$ & $\begin{array}{l}\text { Mono- and few-layer } \\
\mathrm{I}_{2 \mathrm{D}} / \mathrm{I}_{\mathrm{G}}=1.83-2.09 \\
\mathrm{I}_{\mathrm{D}} / \mathrm{I}_{\mathrm{G}}=0.06-0.12\end{array}$ & $\begin{array}{l}\text { Complex purification step } \\
\text { with } 4.4 \mathrm{M} 15 \% \mathrm{HCl} \text { was } \\
\text { used. }\end{array}$ & 94 \\
\hline $\begin{array}{l}\text { Stainless steel sample } \\
\text { container } \\
\text { Nitromethane }\left(\mathrm{CH}_{3} \mathrm{NO}_{2}\right)\end{array}$ & $\begin{array}{l}\text { Calcium carbonate } \\
\text { Magnesium } \\
\text { Ammonium nitrate }\end{array}$ & $\begin{array}{l}\text { Impact velocity }=3.37 \mathrm{~km} / \mathrm{s} \\
\text { Shock pressure }=22.1 \mathrm{GPa} \\
\text { Shock temp. }=5215 \mathrm{~K}\end{array}$ & $\begin{array}{l}\text { Multilayer and nitrogen- } \\
\text { doped } \\
\mathrm{I}_{2 \mathrm{D}} / \mathrm{I}_{\mathrm{G}}=1.43 \\
\mathrm{I}_{\mathrm{D}} / \mathrm{I}_{\mathrm{G}}=0.6 \\
\mathrm{FWHM}_{2 \mathrm{D}}=41\end{array}$ & $\begin{array}{l}\text { For purification, nitric acid } \\
\text { was used under heating } \\
\text { conditions. Then, the } \\
\text { sample need to be filtered } \\
\text { and freeze dry. }\end{array}$ & 95 \\
\hline $\mathrm{RDX}\left(\mathrm{C}_{3} \mathrm{H}_{6} \mathrm{~N}_{6} \mathrm{O}_{6}\right)$ & $\begin{array}{l}\text { Dry ice }\left(\text { Solid } \mathrm{CO}_{2}\right) \\
\text { Calcium hydride }\left(\mathrm{CaH}_{2}\right) \\
\text { Ammonium nitrate }\end{array}$ & $\begin{array}{l}\text { Impact velocity }=3.37 \mathrm{~km} / \mathrm{s} \\
\text { Shock pressure }=22.1 \mathrm{GPa} \\
\text { Shock temp. }=5215 \mathrm{~K}\end{array}$ & $\begin{array}{l}\text { Nitrogen doped few layer } \\
\text { and few layer } \\
\mathrm{I}_{2 \mathrm{D}} / \mathrm{I}_{\mathrm{G}}=1.63 \\
\mathrm{I}_{\mathrm{D}} / \mathrm{I}_{\mathrm{G}}=0.89\end{array}$ & $\begin{array}{l}\text { Diluted hydrochloric acid } \\
\text { were used for purification. } \\
\text { RDX is a more energetic } \\
\text { explosive than } \\
\text { trinitrotoluene (TNT) which } \\
\text { is quite dangerous. }\end{array}$ & 96 \\
\hline
\end{tabular}




\subsection{Sonication}

Sonication is a potent tool for extracting nanomaterials from bulk starting material ${ }^{97,98}$ and it was also widely used to suppress the aggregation of carbon nanomaterials in solvents. Before graphene became prevalent, there were a number of groups that had studied exfoliation of CNTs in solvents ${ }^{99}$. One of them, Bergin et al. 100 found that solvents with surface energy close to that of CNTs would be a good medium to disperse them. Graphite has a surface energy comparable to that of CNTs, hence, the exfoliation of graphite to graphene in certain solvents that had been used for CNTs would be possible. When solvents with surface energies close to that of graphene is used (i.e. around $68 \mathrm{~mJ} / \mathrm{m}^{2}$ ) ${ }^{101}$, the mixing enthalpy is minimized, which favors the graphite exfoliation process.

Khan et al. ${ }^{102}$ demonstrated preparation of GFs in NMP at a concentration up to $1.2 \mathrm{mg} / \mathrm{mL}$ via an extended bath sonication for up to $460 \mathrm{~h}$ or $\sim 19$ days. NMP is a good solvent for exfoliation of graphite via sonication, but unfortunately, its high boiling temperature of $202{ }^{\circ} \mathrm{C}$ forbids to remove it easily ${ }^{103}$. At times, GFs dispersed in high boiling point solvents have been transferred to a low boiling point solvent via solvent exchange ${ }^{104}$ but the obvious solution would be direct exfoliation of graphite to graphene in low boiling point solvent that can also provide a more stable dispersion. O'Neill et al. ${ }^{105}$ demonstrated this by exfoliating graphite via a low power sonication bath in chloroform $\left(\mathrm{CHCl}_{3}\right.$; boiling point $\left.=61.2{ }^{\circ} \mathrm{C}\right)$, isopropanol $\left(\mathrm{C}_{3} \mathrm{H}_{7} \mathrm{OH}\right.$; boiling point $\left.=82.6{ }^{\circ} \mathrm{C}\right)$ and acetone $\left(\mathrm{C}_{3} \mathrm{H}_{6} \mathrm{O}\right.$; boiling point $\left.=56.0^{\circ} \mathrm{C}\right)$.

At this point, it is obvious that many research groups have used NMP as solvent for sonication assisted graphene exfoliation. This phenomenon lies on the surface energy of NMP that well matches to that of graphene, favoring exfoliation to occur freely ${ }^{103}$. However, NMP does not only possess high boiling point but it is also 
relatively expensive. Water can be a good alternative but unfortunately, it has a very high surface energy to be used as exfoliant for graphene. Not to mention, graphene is hydrophobic in nature. With this factors in mind, Lotya et al. ${ }^{106}$ dispersed graphite in surfactant-water solutions, with sodium dodecylbenzene sulfonate (SDBS) as surfactant, in a low power sonic bath for 30 mins. The exfoliated GFs and graphitic flakes were stabilized against re-aggregation by Coulomb repulsion due to the adsorbed surfactants. It would take around 6 weeks for the larger flakes to sediment. Other type of surfactants such as bile salt sodium cholate $\left(\mathrm{C}_{24} \mathrm{H}_{41} \mathrm{NaO}_{6}\right){ }^{107}, 7,7,8,8$ tetracyanoquinodimethane (TCNQ; $\quad \mathrm{C}_{12} \mathrm{H}_{4} \mathrm{~N}_{4}$ ) ${ }^{108}$ and cetyltrimethylammonium bromide (CTAB; $\left.\mathrm{C}_{19} \mathrm{H}_{42} \mathrm{BrN}\right){ }^{109}$ have also been investigated.

Sonication-driven graphene synthesis can be done either by using bathsonication or tip-sonication. Bath-sonication is cheaper but has serious a reproducibility issue. The sonic energy emitted to the sample in bath-sonication can vary depending on the water level, volume of dispersion, vessel shape, power output and exact position of the sample. It also tends to take longer processing time, which can lead to water evaporation. To enhance the performance of bath-sonication, a pressurized ultrasonic bath reactor can be used to intensify the generated ultrasounds. For instance, Štengl ${ }^{110}$ synthesized non-oxidized GFs from powdered natural graphite via high-intensity cavitation fields in a pressurized ( 5 bar) ultrasonic reactor. The cavitation fields that involve the oscillations and collapse of cavities (bubbles) in the liquid provided the source of energy to enhance a wide range of chemical processes and provide physical effects to break down the graphite into GFs ${ }^{111}$.

Table 4 compiles all the work related to the aforementioned sonication-driven processes for GF synthesis. In summary, the exfoliation of graphite via sonication route is heavily dependent on the type of solvent and surfactant being used to contain the 
graphite. It can be concluded that it is essential for the medium to have the required surface energy that matches well with that of graphite, thus favoring the exfoliation process to occur. Since the surface energy of graphene is close to that of CNTs, the type of suitable solvents and surfactants can be easily determined because there have been wide range of studies conducted on these materials for CNT dispersion in the last two decades. This, among others, fosters the fast advancement of this technique. Another advantage of solvent-based techniques for GF synthesis is the readiness of the solution post-exfoliation process to be immediately used for various solution-based application such as nanofluids, spray painting, spin coating, etc. The yield of GFs from sonicationdriven exfoliation process is considerably low but improvement can be achieved by prolonging the sonication time but at the expense of quality of the produced GFs. In most cases, this technique would produce GFs with relatively inferior quality than the other techniques due to scission, which is a known effect induced by sonication that can destroy the graphene sheets and can cause drastic drop of lateral dimensions of GFs 80,112 . Besides, the scalability of this technique is hampered by the utilization of ultrasounds as the energy source. 
Table 4 Examples of GF synthesis via sonication and their characteristics.

\begin{tabular}{|c|c|c|c|c|}
\hline \multicolumn{3}{|c|}{ Sonication conditions } & \multirow[t]{2}{*}{ Graphene quality } & \multirow[t]{2}{*}{ References } \\
\hline Equipment & $\begin{array}{l}\text { Starting material, } \\
\text { solvent/surfactant }\end{array}$ & $\begin{array}{l}\text { Sonication time, sonication } \\
\text { power }\end{array}$ & & \\
\hline $\begin{array}{l}\text { High pressure ultrasound reactor } \\
\text { (HPUS) } \\
\text { Pressure = } 5 \text { bar }\end{array}$ & $\begin{array}{l}\text { Graphite ore } \\
\text { Dichloromethane }\left(\mathrm{CH}_{2} \mathrm{Cl}_{2}\right) \text { or } \\
\text { octanol } \mathrm{C}_{8} \mathrm{H}_{17} \mathrm{OH}\end{array}$ & $\begin{array}{l}10,30,50 \text { minutes } \\
1.3 \mathrm{~kW}\end{array}$ & $\begin{array}{l}\text { Few layer } \\
\text { Size }=\sim 380-1100 \mathrm{~nm}\end{array}$ & 113 \\
\hline $\begin{array}{l}\text { Sonication was preceded with } \\
\text { pressing and homogenization }\end{array}$ & $\begin{array}{l}\text { Carbon nanotubes } \\
\text { NMP }\end{array}$ & 15 minutes & $\begin{array}{l}\mathrm{GFs} \\
\text { Size }=\sim 40-50 \mathrm{~nm} \\
\mathrm{I}_{\mathrm{D}} / \mathrm{I}_{\mathrm{G}}=1.02-1.30\end{array}$ & 114 \\
\hline Low power sonic bath & SDS & 30 minutes & $\begin{array}{l}\text { Monolayer }(\sim 3 \%) \\
\text { Multilayer }(<5 \text { layers }) \\
\mathrm{I}_{\mathrm{D}} / \mathrm{I}_{\mathrm{G}}=0.4\end{array}$ & 106 \\
\hline $\begin{array}{l}\text { Pressurized ultrasound reactor } \\
\text { Pressure }=5 \mathrm{bar} \\
\text { Flowrate }=10 \mathrm{~mL} / \mathrm{min}\end{array}$ & $\begin{array}{l}\text { Natural graphite } \\
\text { Aqueous ethylene glycol }\left(\mathrm{C}_{2} \mathrm{H}_{6} \mathrm{O}_{2}\right)\end{array}$ & $\begin{array}{l}50 \text { minutes } \\
1 \mathrm{~kW}\end{array}$ & $\begin{array}{l}\text { Non-oxidized GFs } \\
\mathrm{I}_{\mathrm{D}} / \mathrm{I}_{\mathrm{G}}=\sim 1.2\end{array}$ & 110 \\
\hline Bath sonicator & $\begin{array}{l}\text { Natural graphite } \\
\text { NMP }\end{array}$ & $\begin{array}{l}\sim 460 \text { hours } \\
23 \mathrm{~W}\end{array}$ & $\begin{array}{l}\text { Multilayer graphene }(<10 \text { layers }) \\
\text { Graphene concentration }=\sim 1.2 \mathrm{mg} / \mathrm{mL} \\
\text { Mean flakes length }=>1 \mu \mathrm{m} \\
\mathrm{I}_{\mathrm{D}} / \mathrm{I}_{\mathrm{G}}=0.3-0.6\end{array}$ & 102 \\
\hline Low power sonic bath & $\begin{array}{l}\text { Natural graphite } \\
\text { Chloroform }\left(\mathrm{CHCl}_{3}\right) \text { or } \\
\text { isopropanol }\left(\mathrm{C}_{3} \mathrm{H}_{7} \mathrm{OH}\right)\end{array}$ & $\begin{array}{l}48 \text { hours } \\
\sim 16 \mathrm{~W}\end{array}$ & $\begin{array}{l}\text { Multilayer graphene } \\
<10 \text { layers for chloroform } \\
<6 \text { layers for isopropanol } \\
\text { Length }=\sim 1 \mu \mathrm{m}\end{array}$ & 105 \\
\hline
\end{tabular}


Natural graphite flakes

Aqueous sodium cholate

Commercial expanded graphite

90 minutes

7,7,8,8-tetracyanoquinodimethane

$\left(\mathrm{C}_{12} \mathrm{H}_{4} \mathrm{~N}_{4}\right)$ anion

Highly ordered pyrolytic graphite

(HOPG)

Cetyltrimethylammonium bromide

$\left(\mathrm{C}_{19} \mathrm{H}_{42} \mathrm{BrN}\right)$
Graphene conc. $=90 \mu \mathrm{g} / \mathrm{mL}$

$\mathrm{I}_{2 \mathrm{D}} / \mathrm{I}_{\mathrm{G}}=0.8-2.1$

$\mathrm{I}_{\mathrm{D}} / \mathrm{I}_{\mathrm{G}}=\sim 0.93$

Single or few-layer

108

2 - 3 layers

Graphene conc. $=\sim 15-20 \mu \mathrm{g} / \mathrm{mL}$

Thickness $=2.36-2.97 \mathrm{~nm}$

FLG

109

Thickness $=\sim 1.18 \mathrm{~nm}$ 


\subsection{Electrochemical exfoliation}

In the past, electrochemical exfoliation has been employed on graphite oxide in electrolyte solution such as sodium sulfate ${ }^{115}$ and phosphate buffer saline (PBS; $\left.\mathrm{K}_{2} \mathrm{HPO}_{4} / \mathrm{KH}_{2} \mathrm{PO}_{4}\right)^{43}$. Nonetheless, the formed $\mathrm{sp}^{3}$ defects cannot be efficiently transformed to $\mathrm{sp}^{2}$ because graphite oxide was used as the starting material. Recent developments of using graphite as the starting material in electrochemical exfoliation were able to increase the quality and quantity of the produced GFs.

A quintessential experimental setup for electrochemical exfoliation would normally involve a working electrode and a counter electrode connected to a power source immersed in an electrolyte. The working electrode is the subject of the process and most often it is in the form of rod or foil made up of graphitic material. The applied potential is the critical force in driving the reaction between the electrolyte and the electrodes leading to the exfoliation of graphite. Either anodic or cathodic potentials are able to drive ions typically from the electrolyte into the graphitic inter-layers, these ions then promote structural deformation of graphite and break down into graphene.

The control of electrode potential is vital in altering the thickness and surface properties of exfoliated graphene. Morales et al. ${ }^{116}$ found that graphene with different degrees of oxidation were obtained by controlling the electrochemical potential. In order to achieve higher precision in controlling the applied potential, a two-electrode system was deemed inadequate. In this regard, a three-electrode system was proposed. Aside from the working electrode and a counter electrode, a three-electrode cell setup has an additional reference electrode. If the working electrode operates as a cathode, then the counter electrode will function as an anode and vice versa. Electrochemically inert materials such as platinum or carbon are normally used as the counter electrode in graphene exfoliation ${ }^{117}$. This is done to avoid any unwanted reaction from happening 
on the counter electrode that would taint the produced GF. The counter electrode is there to complete the circuit for current to flow along with the working electrode and the solution medium. On the other hand, the reference electrode does not take part in the electrochemical exfoliation ${ }^{116}$. There is little to no current flowing through the reference electrode. Reference electrode commonly function as a reference to the working electrode without compromising the stability of the process. Alanyalioğlu et al. ${ }^{117}$ investigated the use of a three-electrode system in SDS solution where graphite rod, Pt foil and Pt wire function as the working electrode, counter electrode and quasireference electrode, respectively. The electrochemical process was divided into two steps. The first step involved the electrochemical intercalation of SDS into graphite which was then followed by electrochemical exfoliation of SDS-intercalated graphite electrode as shown in Fig. 4. By increasing the intercalation potential, the cyclic voltammograms shift to a positive potential, which was attributed to the increase of size or concentration of GFs in the suspensions. Furthermore, the presence of SDS surfactants prevent the GFs from re-stacking in the solution and yield a stable graphene suspension. 


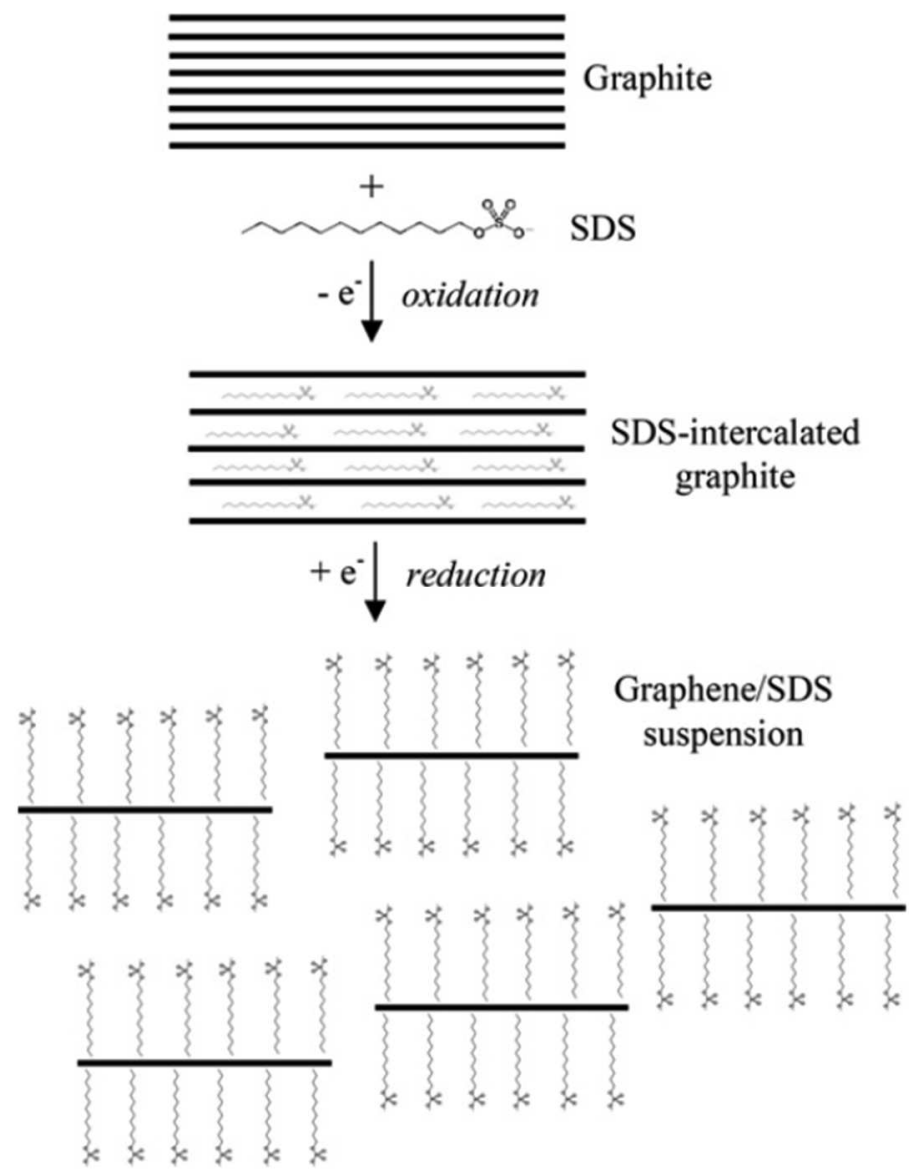

Fig. 4 Schematic illustration of proposed electrochemical exfoliation route to produce graphene/SDS suspension. Reprinted with permission from ${ }^{117}$.

The commonly used graphite rod or foil possesses rather limited surface area and only the outer part is exposed to the electrolyte solution for exfoliation. A graphitic material in the form of powder or porous scaffold would offer significantly larger surface area, thus enhancing the efficiency of the exfoliation process resulting to yield improvement. Sharief et al. ${ }^{118}$ explored this avenue by binding carbon black particles together with electrically conductive polyaniline binder to form a porous electrode with higher surface area than the conventional graphite rod and foil. FLG were obtained from this process. In an earlier work, Alfa et al. ${ }^{119}$ have also synthesized GFs from strongly oxidized carbon black particles that require multi-step chemical route involving harsh chemicals such as hydrazine hydrate $\left(\mathrm{N}_{2} \mathrm{H}_{4}\right)$. Besides, the yield of GF 
production can also be enhanced by using acidic electrolyte but it can cause overoxidation of graphite. This is the reason why an electrolyte system using aqueous inorganic salts at neutral $\mathrm{pH}$ was used in the work by Parvez et al. ${ }^{120}$ and they showed a good balance between the quality and quantity of the produced GFs.

As indicated earlier, electrochemical exfoliation can be performed under anodic and cathodic potentials. The former promote anions of the electrolyte to intercalate into the layer-structured anode due to the electrical field. Simultaneously, it will also intensify the splitting of water into hydroxyl radicals which are highly oxidative mainly towards the graphite electrode ${ }^{121}$. Anodic exfoliation usually involved the use of aqueous electrolytes such as sulfuric acid, sodium benzoate, sodium citrate and triethylmethylammonium-methylsulfate (TEMAMS) ${ }^{122,123}$, resulting to the generation of $\mathrm{HO}^{*}$ radicals from water electrolysis which can disrupt the graphitic structure. Yang et al. 121 carried out electrochemical exfoliation in the presence of antioxidants with the intention of suppressing the formation of radicals. TEMPO $(2,2,6,6-$ tetramethylpiperidin-1-yl)oxyl) assisted electrochemical exfoliation was used to produce large graphene nanosheets with extremely high carbon to oxygen ratio $(\sim 25.3)$. Meanwhile, the generation of oxygenated functional groups is minimal in cathodic exfoliation because it employed organic electrolyte, which is non-oxidizing, in contrast to the aqueous solution used in anodic exfoliation. Therefore, cathodic exfoliation is preferred to minimize the formation of graphite oxide but anodic intercalation is more efficient in terms of the duration of the exfoliation process ${ }^{116}$. Depending on the $\mathrm{pH}$, type and concentration of electrolyte used, the commonly applied potential in anodic exfoliation is $+10 \mathrm{~V}$ or below $44,112,114,117$. However, cathodic exfoliation would require a substantially greater potential (up to $-30 \mathrm{~V}$ in one case) ${ }^{124}$ to produce graphene since a lower cathodic potential would lead to inefficient and slower exfoliation process ${ }^{125}$. 
This is the reason why a cathodic route normally relies on subsequent process such as sonication in order to complete the exfoliation process if a lower applied potentials are used $^{116,126}$.

Regarding the mechanism of electrochemical exfoliation method, it depends on the type of applied potential utilized towards the working electrode ${ }^{127}$ that determines whether it is cathodic or anodic. In cathodic exfoliation, negative current supplies electrons to graphite, creating a negatively charged graphite. The negative charge condition promotes positive charge ions to intercalate between the interlayer spacing of graphene ${ }^{128,129}$. The same is true for the opposite. Positive current withdraws electron from graphite, creating a positive-charged graphite, which promotes intercalation of negative ions between the interlayer spacing of graphene. Exfoliation of graphite occurs as the intercalation or insertion of ions into the interlayer spacing of graphene opening up the van der Waals gap between the graphene layers and subsequent expansion would eventually cause separation from one another. In some cases, the intercalant or cointercalant species evolve into gases, which then assist the exfoliation of the graphite layers. For example, Parvez et al. ${ }^{120}$ used aqueous $\left(\mathrm{NH}_{4}\right)_{2} \mathrm{SO}_{4}$ solution in a 2-electrode cell anodic exfoliation setup. When enough energy was supplied to the process, oxygen and carbon dioxide gases were produced which aided the exfoliation of graphite layers. In another work, $\mathrm{Li}^{+} /$propylene carbonate electrolyte was used and propylene gas was detected from decomposition of the organic solvent on the cathode ${ }^{126}$.

In general, electrochemical exfoliation was normally chosen to synthesize GFs because it is facile, economic, environmentally friendly, non-destructive and operate at ambient pressure and temperature. Furthermore, it is a versatile technique in a way that the characteristics of the produced GFs can be controlled easily, for instance GF thickness can be modulated by merely adjusting the electrode potential. Besides, high 
yield rate of GFs can be achieved by this technique due to its relatively short processing time. For mass production, anodic exfoliation is more preferable than cathodic exfoliation, but oxidation of GFs needs to be minimized in order to meet the structural quality required for application. Table 5 summarizes the works previously described in the electrochemical exfoliation of graphite for GFs synthesis. 
Table 5 Examples of GF synthesis via electrochemical exfoliation and their characteristics.

\begin{tabular}{|c|c|c|c|c|}
\hline Applied potential, remarks & $\begin{array}{l}\text { Configuration, working } \\
\text { electrode, counter electrode, } \\
\text { quasi-ref. electrode }\end{array}$ & Electrolyte, duration & $\begin{array}{l}\text { Characteristics of produced } \\
\text { Graphene }\end{array}$ & References \\
\hline $3 \mathrm{~V}$ & $\begin{array}{l}\text { 2-electrode cell } \\
\text { High purity graphite rods } \\
\text { Pt sheet }\end{array}$ & $\begin{array}{l}\mathrm{NaOH} / \mathrm{H}_{2} \mathrm{O}_{2} / \mathrm{H}_{2} \mathrm{O} \\
10 \mathrm{~min}\end{array}$ & $\begin{array}{l}\text { Anodic few-layer } \\
3 \text { to } 6 \text { layers } \\
\text { Yield }=95 \% \\
I_{D} / I_{G}=0.67\end{array}$ & 44 \\
\hline $2 \mathrm{~V}$ & $\begin{array}{l}\text { 3-electrode cell } \\
\text { Gaphite rod } \\
\text { Pt foil } \\
\text { Pt wire }\end{array}$ & $\operatorname{SDS}(0.1 \mathrm{M})$ & $\begin{array}{l}\text { Multi-layered GFs } \\
\text { Size }_{\text {Average }}=\sim 500 \mathrm{~nm} \\
\text { Thickness }=\sim 1 \mathrm{~nm} \\
\mathrm{I}_{\mathrm{D}} / \mathrm{I}_{\mathrm{G}}=0.124\end{array}$ & 117 \\
\hline $\begin{array}{l}-1.0 \mathrm{~V} \\
\text { Sonication-assisted exfoliation }\end{array}$ & $\begin{array}{l}\text { 3-electrode cell } \\
1 \mathrm{~mm} \text { thick graphite foil } \\
\text { Large surface area carbon } \\
\text { Normal hydrogen electrode }\end{array}$ & Aqueous perchloric acid & $\begin{array}{l}\text { Few layer } \\
3-6 \text { layers } \\
\mathrm{I}_{\mathrm{D}} / \mathrm{I}_{\mathrm{G}}=0.478\end{array}$ & 116 \\
\hline $1,3,5 \mathrm{~V}$ & $\begin{array}{l}\text { 2-electrode cell } \\
\text { Carbon black particles bind with } \\
\text { polyaniline into a porous } \\
\text { electrode } \\
\text { Pt wire }\end{array}$ & $5 \mathrm{~min}, 4 \mathrm{~h}, 3 \mathrm{~h}$ & $\begin{array}{l}\text { Few-layer } \\
\text { Length }=\sim 35 \mathrm{~nm} \\
\text { Width }=\sim 30 \mathrm{~nm} \\
\text { Thickness }=3-8 \mathrm{~nm} \\
\mathrm{I}_{\mathrm{D}} / \mathrm{I}_{\mathrm{G}}=\sim 0.875\end{array}$ & 118 \\
\hline$\sim 2 \mathrm{~V} / \mu \mathrm{m}$ & $\begin{array}{l}\text { 3electrode cell } \\
\text { Carbon nanofiber grown on } \\
\text { stainless steel } \\
\mathrm{Pt} \text { mesh } \\
\mathrm{Ag} / \mathrm{AgCl}\end{array}$ & Sulfuric acid solution $(0.5 \mathrm{M})$ & $\begin{array}{l}\text { Graphene/CNF hybrid } \\
\beta=4930 \\
\text { Turn-on voltage }=1.34 \mathrm{~V} / \mu \mathrm{m}\end{array}$ & 130 \\
\hline
\end{tabular}




\begin{tabular}{|c|c|c|c|c|}
\hline $10 \mathrm{~V}$ & $\begin{array}{l}\text { 2-electrode cell } \\
\text { Graphite flake } \\
\mathrm{Pt}\end{array}$ & $\begin{array}{l}\text { Aqueous sulfate salt } \\
3-5 \mathrm{~min}\end{array}$ & $\begin{array}{l}\text { Yield }=>85 \% \text { (3 layers) } \\
\text { Lateral size }=44 \mu \mathrm{m} \\
\text { C:O ratio }=17.2 \\
\text { Hole mobility }=310 \mathrm{~cm}^{2} / \mathrm{V} \\
\mathrm{I}_{\mathrm{D}} / \mathrm{I}_{\mathrm{G}}=0.25\end{array}$ & 120 \\
\hline $1-10 \mathrm{~V}$ & $\begin{array}{l}\text { 2-electrode cell } \\
\text { HOPG }\end{array}$ & $\begin{array}{l}\text { Sulfuric acid }(0.1 \mathrm{M}) \\
43 \mathrm{~s}\end{array}$ & $\begin{array}{l}\text { GFs } \\
\text { Size }=\sim 10 \mu \mathrm{m}\end{array}$ & 131 \\
\hline $\begin{array}{l}\text { Shear-assisted electrochemical } \\
\text { exfoliation }\end{array}$ & $\mathrm{Pt}$ & & $\mathrm{I}_{\mathrm{D}} / \mathrm{I}_{\mathrm{G}}=0.21-0.32$ & \\
\hline $2.977 \mathrm{~V}$ & $\begin{array}{l}\text { 3-electrode cell } \\
\text { Graphite plate }\end{array}$ & Electrolyte $=$ SDS & $\begin{array}{l}\text { Graphene nanosheets } \\
\text { In-plane crystallite size }\left(L_{\mathrm{a}}\right)=\end{array}$ & 132 \\
\hline $\begin{array}{l}\text { Sonication-assisted } \\
\text { electrochemical exfoliation }\end{array}$ & $\begin{array}{l}\mathrm{Pt} \\
\mathrm{Ag} / \mathrm{AgCl}(3 \mathrm{M} \mathrm{KOH})\end{array}$ & & $26.8 \mathrm{~nm}$ & \\
\hline$+3 \mathrm{~V}$ & $\begin{array}{l}\text { 2-electrode cell } \\
\text { Pre-treated graphite foil } \\
\text { Pt }\end{array}$ & $30 \mathrm{~min}$ & $\begin{array}{l}\text { Graphene nanosheets } \\
\text { Lateral size }=<2 \mu \mathrm{m} \\
\mathrm{I}_{\mathrm{D}} / \mathrm{I}_{\mathrm{G}}=0.60\end{array}$ & 123 \\
\hline & $\begin{array}{l}\text { 2-electrode cell } \\
\text { Rolled graphite foils } \\
\text { Pt foils }\end{array}$ & TEMPO & $\begin{array}{l}\text { Graphene nanosheets } \\
\text { Size }=5-10 \mu \mathrm{m} \\
\mathrm{I}_{\mathrm{D}} / \mathrm{I}_{\mathrm{G}}=<0.1 \\
\mathrm{C} / \mathrm{O}=\sim 25.3\end{array}$ & \\
\hline $\begin{array}{l}-15 \pm 5 \mathrm{~V} \\
\text { Sonication-assisted exfoliation }\end{array}$ & $\begin{array}{l}\text { Graphite in liquid- rechargeable } \\
\text { lithium ion batteries }\end{array}$ & Propylene carbonate & $\begin{array}{l}\text { Few-layer } \\
<5 \text { layers } \\
\text { Yield }=>70 \%\end{array}$ & 126 \\
\hline-15 to $-30 \mathrm{~V}$ & $\begin{array}{l}\text { 2-electrode cell } \\
\text { HOPG rod } \\
\text { Pt-sheet }\end{array}$ & $\begin{array}{l}\text { N-butyl, methylpyrrolidinium } \\
\text { bis(trifluoromethylsulfonyl)imide } \\
\left(\mathrm{BMPTF}_{2} \mathrm{~N}\right)\end{array}$ & $\begin{array}{l}2-5 \text { layers graphene sheets, low } \\
\text { levels of oxygen }(2.7 \text { at. } \% \text { of } O) \\
I_{D} / I_{G}<0.05\end{array}$ & 124 \\
\hline
\end{tabular}




\subsection{Shear exfoliation in liquid}

Sonication-based exfoliation generally operates in ultrasonic water bath or via probe-tip sonicator which has limited scalability. Sonic tips and sonic baths can only be effective when processing volumes no larger than a few hundred milliliters $102,103,133,134$. The energy transfer from the energy source to the liquid medium is relatively poor leading to low production rates. Expanding the volume of the liquid medium in a sonication-based exfoliation would weaken the sonication energy. At manufacturing scale, sonication of graphite to graphene does not seem to be a viable method. Plus, it was reported that sonication-based exfoliation has a sublinear increase in GF concentration $\left(\mathrm{C}_{\mathrm{GF}}\right)$ with sonication time $(t)$, represented by $\mathrm{C}_{\mathrm{GF}} \propto \sqrt{t}$ which means that the sonication time has significantly less impact at higher concentration ${ }^{102,134}$. Recent works demonstrated that shear mixing of graphite in aqueous surfactants or solvents could lead to efficient exfoliation to FLG ${ }^{135,136}$ as a scalable alternative to sonication-based exfoliation. For shear-based exfoliation, GF concentration typically scaled as $\mathrm{C}_{\mathrm{GF}} \propto t$ in surfactant solutions ${ }^{136}$.

In the past, shear mixing was extensively used to disperse and scatter nanoparticles in liquid mediums by breaking up the weakly-bound nanoparticle agglomerates ${ }^{137}$ but it can also be employed to disrupt the stronger van der Waals forces in the graphite layers to produce graphene at a lower energy density than that of ultrasonic probe ${ }^{136,138}$. A typical shear-based exfoliation would involve the use of rotating blade or rotor in a solvent, surfactant or aqueous medium mixed with graphite. It is also critical that shear-exfoliation can be done without any pre-treatment such as intercalation so that the potential to scale the technology is not limited by the intercalation step. For example, the additional "wireless" electrochemical intercalation of graphite flakes prior to high-shear exfoliation in the work by Bjerglund et al. ${ }^{139}$ was 
seen as stumbling block for commercialization although a remarkable GF yield of around $16 \%$ was obtained.

In the early days of shear exfoliation of graphite in liquid, Chen et al. ${ }^{138}$ utilized shearing vortex fluidic films in a rapidly rotating tube $(7000 \mathrm{rpm})$ inclined at $45^{\circ}$ as shown in Fig. 5. The degree of the inclination plays a vital role as the shearing stress arises from interactions between centrifugal and gravitational forces. Slippage of graphene also occurs on the walls of the tube as the graphite bulk material was held against the tube walls by centrifugal forces. Without the inclination, there would be no exfoliation as centrifugal forces would be the lone force present, which resulted in less turbulence within the liquid medium. Unfortunately, this method is considered a 'soft energy' source whereby the shear stress is quite limited for the exfoliation process, thus resulting to a low GF yield ( 1 wt.\%). In order to achieve higher yield, the level of shear stress needs to be raised. One way to elevate the shear stress is by incorporating the fluid dynamics phenomena in the exfoliation process such as turbulence-induced shear stress ${ }^{140}$.

(a)

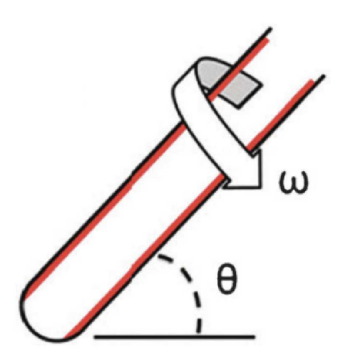

(b)

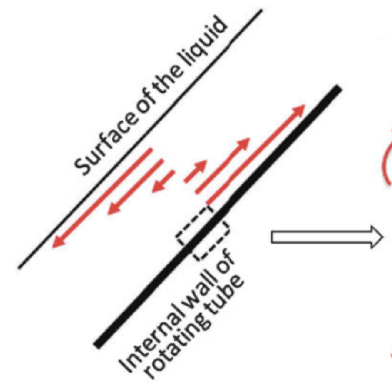

(c)

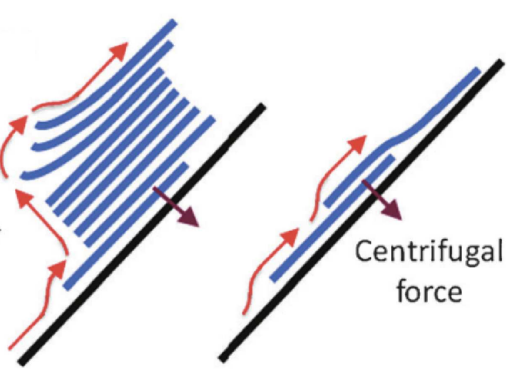

Fig. 5 (a) Schematic illustration of exfoliation process using a vortex fluidic device inclined at $45^{\circ}$; (b) Micro-fluidic flow velocity of the rotating tube; (c) Exfoliation process from centrifugal and gravitational forces; (d) Slippage of graphene layer on the inner surface of the tube. Adapted with permission from ${ }^{138}$. 
Paton et al. ${ }^{136}$ worked on high-shear mixing of graphite in sodium cholate $(\mathrm{NaC})$ and NMP via a rotor-stator system which resulted in large-scale exfoliation of un-oxidized graphene nanosheets. The rotor-stator system provided higher shear stress for the exfoliation phenomenon. A model was also developed showing that exfoliation occurs once the local minimum shear rate exceeds $10^{4} \mathrm{~s}^{-1}$. The experimentations were carried out initially in a $5 \mathrm{~L}$ high-shear mixer (rotor diameter $=3.2 \mathrm{~cm}$ ) and later expanded into a $300 \mathrm{~L}$ high-shear mixer (rotor diameter $=11 \mathrm{~cm}$ ). The large-scale trials yielded $21 \mathrm{~g}$ of GFs per batch with low $\mathrm{I}_{\mathrm{D}} / \mathrm{I}_{\mathrm{G}}$ and production rates as high as $5.3 \mathrm{~g} / \mathrm{h}$. Both followed the same scaling law and it was estimated that production rates of 100 $\mathrm{g} / \mathrm{h}$ are possible at $10 \mathrm{~m}^{3}$ volume. Additionally, the need for turbulent energy for exfoliation was also proven to be unnecessary as exfoliation can still happen even when turbulence did not fully develop at Reynolds number $(\mathrm{Re})$ less than 10,000. This means that as long as the mixer can achieve this minimum shear rate, it can be used to produce GFs, regardless of whether turbulence is achieved or not. However, it is important to note that a higher Re number represents higher shear stress and hence GF production at higher yield compared to that produced in laminar flow can be expected. In a work by Varrla et al. ${ }^{135}$, a Kenwood kitchen blender was employed to produce graphene. Graphene was able to be synthesized because the mean turbulent shear stress within the kitchen blender exceeds the critical shear rate for exfoliation of graphite. From this study, it appeared that the use of an industrial rotating blade continuous stirred tank reactor (CSTR) can be an upgrade for a large-scale production of GFs.

Tran et al. ${ }^{141}$ showed that high shear mixing of graphite powders in NMP with the implementation of Taylor vortex flow regime resulted in an efficient exfoliation into FLGs with a high yield. This secondary flow ensued when the inner cylinder 
between two concentric cylinders' rotation exceeds a critical value with the outer cylinder fixed as shown in Fig. 6. The critical value for Taylor vortex flow can be identified using Taylor number $\left(\mathrm{T}_{\mathrm{a}}\right)$ as illustrated in Eq. 4. $\Omega$ is the angular velocity, $\mathrm{R}_{\mathrm{i}}$ is the radius of the inner cylinders, $R_{o}$ is the radius of outer cylinders and $v$ is the kinematic velocity. Taylor instability sets in when $\mathrm{T}_{\mathrm{a}}$ exceeds $\sim 1700$ as highly turbulent Taylor vortex flow is developed prompting a high wall shear stress and pressure sufficient to produce high yield of GFs. Besides, shear exfoliation is quite flexible and can be combined with other technique to improve the overall performance of the process.

$T_{a}=\frac{\Omega^{2} R_{i}\left(R_{o}-R_{i}\right)^{3}}{v^{2}}$

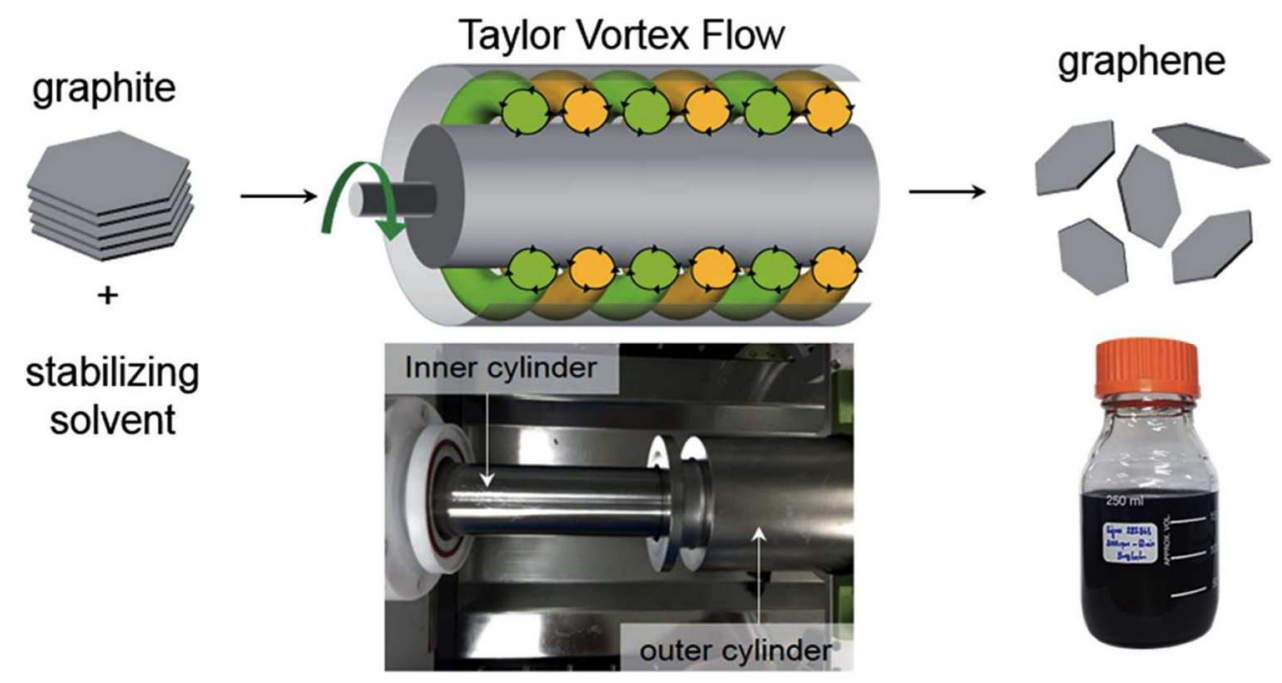

Fig. 6 Schematic illustration of GFs synthesis via shear-based exfoliation using Taylor vortex flow. Reprinted with permission from ${ }^{141}$.

Table 6 summarizes the works previously described in the shear exfoliation of graphite in liquid for GF synthesis. Generally, this technique shares the same advantages as 
sonication-driven exfoliation technique such as wide selection range of solvents and surfactants, and the readiness for immediate utilization for solution-based applications. However, in the aspect of yield production and quality of synthesized GFs, shear exfoliation technique is superior to that based on sonication. In fact, this technique has demonstrated the highest production rate $(5.3 \mathrm{~g} / \mathrm{h})$ of high quality GFs ${ }^{136}$ compared to the other techniques, which offers great potential for scale-up and mass production. 
Table 6 Examples of GF synthesis via shearing-based exfoliation and their characteristics.

\begin{tabular}{|c|c|c|c|c|}
\hline \multicolumn{3}{|l|}{ Shearing conditions } & \multirow[t]{2}{*}{ Graphene quality } & \multirow[t]{2}{*}{ References } \\
\hline Equipment, remarks & Solvent/surfactant & Duration, speed & & \\
\hline $\begin{array}{l}\text { Silverson model L5M mixer } \\
\text { Rotor diameter }=32 \mathrm{~mm} \\
\text { Liquid volume }=4.5 \mathrm{~L}\end{array}$ & NMP and $\mathrm{NaC}$ (sodium cholate) & $\begin{array}{l}20 \mathrm{~min} \\
4500 \mathrm{rpm}\end{array}$ & $\begin{array}{l}\text { FLG nanosheets } \\
\text { Size }=300-800 \mathrm{~nm} \\
\text { Thickness } \\
\mathrm{I}_{\mathrm{D}} / \mathrm{I}_{\mathrm{G}}=0.17-0.37\end{array}$ & 136 \\
\hline $\begin{array}{l}\text { High-shear mixer } \\
\text { Rotor diameter }=110 \mathrm{~mm} \\
\text { Liquid volume }=300 \mathrm{~L}\end{array}$ & & $\begin{array}{l}5 \mathrm{~min}-4 \text { hours } \\
3000 \mathrm{rpm}\end{array}$ & $\begin{array}{l}\text { Production rate }=5.3 \mathrm{~g} / \mathrm{h} \\
\text { Conc. }=0.07 \mathrm{mg} / \mathrm{mL} \\
\mathrm{I}_{\mathrm{D}} / \mathrm{I}_{\mathrm{G}}=0.18\end{array}$ & 136 \\
\hline $\begin{array}{l}\text { Two co-axial cylinders Taylor- } \\
\text { Couette flow reactor }\end{array}$ & NMP & $\begin{array}{l}60 \mathrm{~min} \\
3000 \mathrm{rpm}\end{array}$ & $\begin{array}{l}\text { Few-layer GFs } \\
\text { Lateral size }=500-1500 \mathrm{~nm} \\
\text { Thickness }=<3 \mathrm{~nm} \\
\mathrm{I}_{\mathrm{D}} / \mathrm{I}_{\mathrm{G}}=\sim 0.14 \\
\text { Yield }=5 \%\end{array}$ & 141 \\
\hline $\begin{array}{l}\text { Kenwood BL370 series kitchen } \\
\text { blender } \\
\text { Working volume }=500 \mathrm{~L} \\
\text { Motor }=400 \mathrm{~W}\end{array}$ & Fairy washing-up liquid (FL) & $\begin{array}{l}5-30 \mathrm{~min} \\
18000 \mathrm{rpm}\end{array}$ & $\begin{array}{l}\text { Lateral size }=\text { Hundreds of } \mathrm{nm} \\
\text { Max flake length }=\sim 3.3 \mu \mathrm{m} \\
\mathrm{I}_{\mathrm{D}} / \mathrm{I}_{\mathrm{G}}=0.3-0.7 \\
\mathrm{FWHM}=\sim 45 \mathrm{~cm}^{-1}\end{array}$ & 135 \\
\hline $\begin{array}{l}\text { Vortex fluidic device } \\
\text { Tube inclination }=45^{\circ}\end{array}$ & NMP & $\begin{array}{l}30 \mathrm{~min} \\
7000 \mathrm{rpm}\end{array}$ & $\begin{array}{l}\text { Few layer GFs } \\
\text { Yield }=\sim<1 \mathrm{wt} . \% \\
\text { Max size }=1 \mu \mathrm{m} \\
\text { Thickness }=\sim 1 \mathrm{~nm}\end{array}$ & 138 \\
\hline
\end{tabular}


Pro Scientific PRO250 rotor-stator

Shear rate $=33000 \mathrm{~s}^{-1}$

$6000 \mathrm{rpm}$

Aqueous modified polyviny

High-speed steel blender

Blade diameter $=28 \mathrm{~mm}$ alcohol (mPVOH)
Size $=0.4-1.5 \mu \mathrm{m}$

Thickness $=4-6$ layers

Yield $=16 \%$

$\mathrm{I}_{\mathrm{D}} / \mathrm{I}_{\mathrm{G}}=\sim 0.24$

Size $=\sim 400 \mathrm{~nm}$

Thickness $=5-10$ layers
139 


\section{$3 \quad$ Future Prospect}

Safety aspect is the top consideration when comes to any kind of production processes. From the methods presented in this review, explosion-based exfoliation would be the most dangerous since it involves the use of explosive materials. These materials would need special care and safety precautions while also demand lengthy and complex procedures for purchasing them. This is different than the flammable gases widely used in CVD process since the threat of them being dangerous to the operators have been exhaustively investigated and the standard operating procedures in handling them have long been established. There are also too many unknown variables to provide the necessary external energy to breakdown graphite in explosion-based exfoliation. Even slight difference in the position and quantity of the explosives can bring about different quality of GFs.

That leaves us with electrochemical, sonication, ball milling and shear exfoliation in liquid. Among others, the potential to scale-up the process would be the most vital aspect in comparing them. Based on the detail description for each method given in this review, it appeared that the limited processing volume for sonication and electrochemical-based exfoliation restricts their scalability. In contrast, to scale-up shear in liquid and ball milling is rather easy and this is logical since they have been in the commercial sector for a very long time. There are various CSTRs and ball-mills available in the market that can be used to replicate and scale-up the laboratory-scale process. Between these two methods, shear exfoliation in liquid offers greater advantage due to simpler operation, since the presence of inert gas in the case of dry milling and the requirement for an additional purification step in wet milling makes milling process rather complicated. Furthermore, ball milling requires longer 
processing cycle. Factoring these aspects into the equation, shear exfoliation in liquid offers the brightest prospect toward large-scale and low-cost GF synthesis.

Scaling up GF production from laboratory-scale presents a huge challenge. It is a hurdle that needs to be overcame if a future where graphene is cheaply and easily mass-produced is ever to be achieved. There is no doubt that, with concentrated and cooperative efforts in research and developments by the private and government sectors, GF production methods will quickly become more productive and costeffective in the near future. In particular, for shear exfoliation in liquid, the critical aspect needed for scale-up is to have a high shear rates and efficient processes, which can be achieved through a careful design of the flow regime which involves the aspect of flow dynamics. At the same time, the issue of process-induced defects and disparity in sizes and number of layers of the produced GFs, which are common problem for all synthesis methods, should also be tackled.

\section{Conclusion}

In this review, we describe the synthesis methods of GFs by using ball milling, explosion, sonication, electrochemical and shear exfoliation in liquid. The mechanism of each method was described in the respective sub-sections. Results from the recent works were compiled, presented and discussed. Finally, the methods were compared and their future prospects were expressed. After a comprehensive analysis on the GF synthesis methods presented in this review, shear exfoliation in liquid has emerged to be the brightest prospect for the scaling-up GF production, not only because it is relatively safe, simple and cheap but also due to its technological maturity. Therefore, a coordinated effort in leading the research towards large scale and low cost production by focusing on shearing-based exfoliation is highly recommended to speed up the 
commercial availability of GFs and fulfils the surging demand of GFs in various technological applications to produce next-generation devices. 


\section{Acknowledgements}

The authors gratefully acknowledge the financial support provided by the Government of Malaysia (MyBrain), USM-NanoMITE (203/PJKIMIA/6720009) and Fundamental Research Grant Scheme (203/PJKIMIA/6071335).

\section{References}

1 X. Wang, Y. Yang, G. Jiang, Z. Yuan and S. Yuan, A facile synthesis of boron nitride nanosheets and their potential application in dye adsorption, Diamond and Related Materials, 2018, 81, 89-95.

2 M. Örnek, K. M. Reddy, C. Hwang, V. Domnich, A. Burgess, S. Pratas, J. Calado, K. Y. Xie, S. L. Miller, K. J. Hemker and R. A. Haber, Observations of explosion phase boron nitride formed by emulsion detonation synthesis, Scripta Materialia, 2018, 145, 126-130.

3 P. Zhuang, W. Lin, B. Xu, W. Cai, P. Zhuang, W. Lin, B. Xu and W. Cai, Oxygen-assisted synthesis of hexagonal boron nitride films for graphene transistors Oxygen-assisted synthesis of hexagonal boron nitride films for graphene transistors, Applied Physics Letters, 2017, 111(203103).

$4 \quad$ K. Wada, K. Tomita and M. Takashiri, Fabrication of bismuth telluride nanoplates via solvothermal synthesis using different alkalis and nanoplate thin films by printing method, Journal of Crystal Growth, 2017, 468, 194-198.

5 P. Termsaithong and A. Rodchanarowan, Synthesis of ternary semiconductor silver bismuth telluride by chemical bath deposition, Key Engineering Materials, 2017, 751, 489-493.

6 N. D. Desai, K. V. Khot, V. B. Ghanwat, S. D. Kharade and P. N. Bhosale, Surfactant mediated synthesis of bismuth selenide thin films for photoelectrochemical solar cell applications, Journal of Colloid and Interface Science, 2018, 514, 250-261.

7 Q. Jiang, X. Chen, L. Li, C. Feng and Z. Guo, Synthesis and Electrochemical Properties of Molybdenum Disulfide/Carbon Microsphere Composite, Journal of Electronic Materials, 2017, 46(2), 1079-1087.

8 K. N. Solanki, R. M. Cadambi, S. Srikari and S. R. Shankapal, Synthesis of Nanostructured Molybdenum Disulfide by Chemical Vapour Deposition, Materials Today: Proceedings, 2017, 4(10), 11134-11140.

9 D. J. Sathe, P. A. Chate, P. P. Hankare, A. H. Manikshete and A. S. Aswar, A novel route for synthesis, characterization of molybdenum diselenide thin films and their photovoltaic applications, Journal of Materials Science: Materials in Electronics, 2013, 24(2), 438-442.

10 B. B. Wang, K. Zheng, X. X. Zhong, D. Gao and B. Gao, Synthesis and structure of molybdenum diselenide nanosheets produced from $\mathrm{MoO} 3$ and $\mathrm{Se}$ powders, Journal of Alloys and Compounds, 2017, 695, 27-34.

11 J. C. Park, S. J. Yun, H. Kim, J. H. Park, S. H. Chae, S. J. An, J. G. Kim, S. M. Kim, K. K. Kim and Y. H. Lee, Phase-Engineered Synthesis of CentimeterScale 1T'- and 2H-Molybdenum Ditelluride Thin Films, ACS Nano, 2015, 9(6), 
6548-6554.

12 S. H. Choi, S. Boandoh, Y. H. Lee, J. S. Lee, J.-H. Park, S. M. Kim, W. Yang and K. K. Kim, Synthesis of Large-Area Tungsten Disulfide Films on PreReduced Tungsten Suboxide Substrates, ACS Applied Materials \& Interfaces, 2017, 9, 43021-43029.

13 S. J. Yun, S. M. Kim, K. K. Kim and Y. H. Lee, A systematic study of the synthesis of monolayer tungsten diselenide films on gold foil, Current Applied Physics, 2016, 16(9), 1216-1222.

14 Y. Z. Chen, H. Medina, T. Y. Su, J. G. Li, K. Y. Cheng, P. W. Chiu and Y. L. Chueh, Ultrafast and low temperature synthesis of highly crystalline and patternable few-layers tungsten diselenide by laser irradiation assisted selenization process, ACS Nano, 2015, 9(4), 4346-4353.

15 P. Vogt, P. Capiod, M. Berthe, A. Resta, P. De Padova, T. Bruhn, G. Le Lay, B. Grandidier, P. Vogt, P. Capiod, M. Berthe, A. Resta, P. De Padova, T. Bruhn and G. Le Lay, Synthesis and electrical conductivity of multilayer silicene Synthesis and electrical conductivity of multilayer silicene, Applied Physics Letters, 2014, 104(021602), 1-6.

16 P. De Padova, H. Feng, J. Zhuang, Z. Li, A. Generosi, B. Paci, C. Ottaviani, C. Quaresima, B. Olivieri, M. Krawiec and Y. Du, Synthesis of Multilayer Silicene on $\operatorname{Si}(111) \sqrt{ } 3 \times \sqrt{3}-\mathrm{Ag}$, The Journal of Physical Chemistry C, 2017, 121(48), 27182-27190.

17 A. Khandelwal, K. Mani, M. H. Karigerasi and I. Lahiri, Phosphorene - The two-dimensional black phosphorous: Properties, synthesis and applications, Materials Science and Engineering B: Solid-State Materials for Advanced Technology, 2017, 221, 17-34.

18 A. H. Woomer, T. W. Farnsworth, J. Hu, R. A. Wells, C. L. Donley and S. C. Warren, Phosphorene: Synthesis, Scale-Up, and Quantitative Optical Spectroscopy, ACS Nano, 2015, 9(9), 8869-8884.

19 E. Aktürk, O. Ü. Aktürk and S. Ciraci, Single and bilayer bismuthene: Stability at high temperature and mechanical and electronic properties, Physical Review $B, 2016,94(1), 1-9$.

20 J. M. Kehoe, J. H. Kiley, J. J. English, C. A. Johnson, R. C. Petersen and M. M. Haley, Carbon Networks Based on Dehydrobenzoannulenes. 3. Synthesis of Graphyne Substructures 1, Organic Letters, 2000, 2(7), 969-972.

21 A. K. Dearden and J. Crean, New materials graphyne, graphdiyne, graphone, and graphane: review of properties, synthesis, and application in nanotechnology, Nanotechnology, Science and Applications, 2014, 7, 1-29.

22 M. Q. Arguilla, S. Jiang, B. Chitara and J. E. Goldberger, Synthesis and stability of two-dimensional Ge/Sn graphane alloys, Chemistry of Materials, 2014, 26(24), 6941-6946.

23 M. Ali, S. Abdul-Rashid, M. N. Hamidon and F. Md Yasin, Simple synthesis of large-area multilayer graphene films on dielectric substrate via chemical vapor deposition route (Synthesis of MLG films on dielectric substrates via CVD route), International Conference on Advances in Electrical, Electronic and Systems Engineering, ICAEES, 2016, 7888055, 293-296.

24 A. T. Murdock, C. D. van Engers, J. Britton, V. Babenko, S. S. Meysami, H. Bishop, A. Crossley, A. A. Koos and N. Grobert, Targeted removal of copper foil surface impurities for improved synthesis of CVD graphene, Carbon, 2017, $122,207-216$.

25 A. K. Geim and K. S. Novoselov, The rise of graphene, Nature Materials, 
2007, 6(3), 183-191.

26 K. S. Novoselov, A. K. Geim, S. V. Morozov, D. Jiang, Y. Zhang, S. V. Dunonos, I. V. Grigorieva and A. A. Firsov, Electric Field Effect in Atomically Thin Carbon Films, Science, 2004, 306(5696), 666-669.

27 M. K. Nizam, D. Sebastian, M. I. Kairi, M. Khavarian and A. R. Mohamed, Synthesis of graphene flakes over recovered copper etched in ammonium persulfate solution, Sains Malaysiana, 2017, 46(7), 1039-1045.

28 S. Chae, M. A. Bratescu and N. Saito, Synthesis of Few-Layer Graphene by Peeling Graphite Flakes via Electron Exchange in Solution Plasma, Journal of Physical Chemistry C, 2017, 121(42), 23793-23802.

29 F. Ghaemi, L. C. Abdullah, N. M. A. Nik Abd Rahman, S. U. F. S. Najmuddin, M. M. Abdi and H. Ariffin, Synthesis and comparative study of thermal, electrochemical, and cytotoxicity properties of graphene flake and sheet, Research on Chemical Intermediates, 2017, 43(8), 4981-4991.

30 H. An, W.-G. Lee and J. Jung, Synthesis of graphene ribbons using selective chemical vapor deposition, Current Applied Physics, 2012, 12(4), 1113-1117.

31 F. Liu, X. Shen, Y. Wu, L. Bai, H. Zhao and X. Ba, Synthesis of ladder-type graphene ribbon oligomers from pyrene units, Tetrahedron Letters, 2016, 57(37), 4157-4161.

32 S. Bhaviripudi, X. Jia, M. S. Dresselhaus and J. Kong, Role of kinetic factors in chemical vapor deposition synthesis of uniform large area graphene using copper catalyst, Nano Letters, 2010, 10(10), 4128-4133.

33 Z. Yan, J. Lin, Z. Peng, Z. Sun, Y. Zhu, L. Li, C. Xiang, E. L. Samuel, C. Kittrell and J. M. Tour, Toward the synthesis of wafer-scale single-crystal graphene on copper foils, ACS Nano, 2012, 6(10), 9110-9117.

34 A. Bianco, H. M. Cheng, T. Enoki, Y. Gogotsi, R. H. Hurt, N. Koratkar, T. Kyotani, M. Monthioux, C. R. Park, J. M. D. Tascon and J. Zhang, All in the graphene family - A recommended nomenclature for two-dimensional carbon materials, Carbon, 2013, 65, 1-6.

35 X. S. Li, Y. W. Zhu, W. W. Cai, M. Borysiak, B. Y. Han, D. Chen, R. D. Piner, L. Colombo and R. S. Ruoff, Transfer of Large-Area Graphene Films for HighPerformance Transparent Conductive Electrodes, Nano Letters, 2009, 9(12), 4359-4363.

36 W. Yang and C. Wang, Graphene and the related conductive inks for flexible electronics, Journal of Materials Chemistry C, 2016, 4(30), 7193-7207.

37 K. Arapov, E. Rubingh, R. Abbel, J. Laven, G. de With and H. Friedrich, Conductive Screen Printing Inks by Gelation of Graphene Dispersions, Advanced Functional Materials, 2016, 26(4), 586-593.

38 S. Stankovich, D. A. Dikin, R. D. Piner, K. A. Kohlhaas, A. Kleinhammes, Y. Jia, Y. Wu, S. T. Nguyen and R. S. Ruoff, Synthesis of graphene-based nanosheets via chemical reduction of exfoliated graphite oxide, Carbon, 2007, 45(7), 1558-1565.

39 S. Dayou, B. Vigolo, J. Ghanbaja, G. Medjahdi, M. Z. Ahmad Thirmizir, H. Pauzi and A. R. Mohamed, Direct Chemical Vapor Deposition Growth of Graphene Nanosheets on Supported Copper Oxide, Catalysis Letters, 2017, 147(8), 1988-1997.

40 I. Jeon, Y. Shin, G. Sohn, H. Choi, S. Bae, J. Mahmood and S. Jung, Edgecarboxylated graphene nanosheets via ball milling, Proceedings of the National Academy of Sciences, 2012, 109, 5588-5593.

41 Y. Yao, Z. Lin, Z. Li, X. Song, K.-S. Moon and C. Wong, Large-scale 
production of two dimensional nanosheets, Journal of Materials Chemistry, 2012, 22(27), 13494-13499.

42 J. N. Coleman, U. Khan, K. Young, A. Gaucher, S. De, R. J. Smith, I. V Shvets, S. K. Arora, G. Stanton, H. Kim, K. Lee, G. T. Kim, G. S. Duesberg, T. Hallam, J. J. Boland, J. J. Wang, J. F. Donegan, J. C. Grunlan, G. Moriarty, A. Shmeliov, R. J. Nicholls, J. M. Perkins, E. M. Grieveson, K. Theuwissen, D. W. Mccomb, P. D. Nellist and V. Nicolosi, Two-Dimensional Nanosheets Produced by Liquid Exfoliation of Layered Materials, Science, 2011, 331, 568571.

43 H. Guo, X. Wang, Q. Qian, F. Wang and X. Xia, A Green Approach to the Synthesis of Graphene Nanosheets, ACS Nano, 2009, 3(9), 2653-2659.

44 K. S. Rao, J. Senthilnathan, Y.-F. Liu and M. Yoshimura, Role of Peroxide Ions in Formation of Graphene Nanosheets by Electrochemical Exfoliation of Graphite, Scientific Reports, 2015, 4(1), 4237.

45 J. Wang, J. Huang, R. Yan, F. Wang, W. Cheng, Q. Guo and J. Wang, Graphene microsheets from natural microcrystalline graphite minerals: scalable synthesis and unusual energy storage, J. Mater. Chem. A, 2015, 3(6), 31443150 .

46 D. W. Chang and J.-B. Baek, Eco-friendly synthesis of graphene nanoplatelets, J. Mater. Chem. A, 2016, 4(40), 15281-15293.

47 E. M. Milner, N. T. Skipper, C. A. Howard, M. S. P. Shaffer, D. J. Buckley, K. A. Rahnejat, P. L. Cullen, R. K. Heenan, P. Lindner and R. Schweins, Structure and morphology of charged graphene platelets in solution by small-angle neutron scattering, Journal of the American Chemical Society, 2012, 134(20), 8302-8305.

48 J. Yang, Q. Liao, X. Zhou, X. Liu and J. Tang, Efficient synthesis of graphenebased powder via in situ spray pyrolysis and its application in lithium ion batteries, RSC Advances, 2013, 3(37), 16449.

49 Y. Lv, L. Yu, C. Jiang, S. Chen and Z. Nie, Synthesis of graphene nanosheet powder with layer number control via a soluble salt-assisted route, $R S C$ Advances, 2014, 4(26), 13350.

50 H. Teymourinia, M. Salavati-Niasari, O. Amiri and M. Farangi, Facile synthesis of graphene quantum dots from corn powder and their application as down conversion effect in quantum dot-dye-sensitized solar cell, Journal of Molecular Liquids, 2018, 251, 267-272.

51 H. Teymourinia, M. Salavati-Niasari, O. Amiri and H. Safardoust-Hojaghan, Synthesis of graphene quantum dots from corn powder and their application in reduce charge recombination and increase free charge carriers, Journal of Molecular Liquids, 2017, 242, 447-455.

52 B. S. Wang, P. Chia, L. Chua, L. Zhao, R. Png, S. Sivaramakrishnan, M. Zhou, R. G. Goh, R. H. Friend, A. T. Wee and P. K. Ho, Band-like Transport in Surface-Functionalized Highly Solution-Processable Graphene Nanosheets, Advanced Materials, 2008, 20, 3440-3446.

53 S. Stankovich, R. D. Piner, S. T. Nguyen and R. S. Ruoff, Synthesis and exfoliation of isocyanate-treated graphene oxide nanoplatelets, Carbon, 2006, 44, 3342-3347.

54 S. Gilje, R. B. Kaner, G. G. Wallace, D. A. N. Li and M. B. Mu, Processable aqueous dispersions of graphene nanosheets, Nature Nanotechnology, 2008, 3, 101-105.

55 S. Stankovich, R. D. Piner, X. Chen, N. Wu, T. Nguyen and R. S. Ruoff, Stable 
aqueous dispersions of graphitic nanoplatelets via the reduction of exfoliated graphite oxide in the presence of poly (sodium 4-styrenesulfonate), Journal of Materials Chemistry, 2006, 16, 155-158.

56 Y. Xu, H. Bai, G. Lu, C. Li and G. Shi, Flexible Graphene Films via the Filtration of Water-Soluble Noncovalent Functionalized Graphene Sheets, Journal of the American Chemical Society, 2008, 130(18), 5856-5857.

57 E. J. Kim, A. Desforges, L. Speyer, J. Ghanbaja, J. Gleize, P. Estellé and B. Vigolo, Graphene for Water-Based Nanofluid Preparation: Effect of Chemical Modifications on Dispersion and Stability, Journal of Nanofluids, 2017, 6(3), 603-613.

58 B. C. Brodie, On the Atomic Weight of Graphite, Philosophical Transactions of the Royal Society of London, 1859, 149, 249-259.

59 W. S. Hummers and R. E. Offeman, Preparation of Graphitic Oxide, Journal of the American Chemical Society, 1958, 80(6), 1339.

60 D. Marcano, D. Kosynkin and J. Berlin, Improved synthesis of graphene oxide, ACS Nano, 2010, 4(8), 4806-4814.

61 A. D. McNaught and A. Wilkinson, IUPAC Compendium of Chemical Terminology, Blackwell Scientific Publications, Oxford, 2nd ed. (the 'Gold Book'), 2014.

62 B. Gadgil, P. Damlin and C. Kvarnström, Graphene vs. reduced graphene oxide: A comparative study of graphene-based nanoplatforms on electrochromic switching kinetics, Carbon, 2016, 96, 377-381.

63 G. Wang, J. Yang, J. Park, X. Gou, B. Wang, H. Liu and J. Yao, Facile synthesis and characterization of graphene nanosheets, Phys. Chem C, 2008, 112(22), 8192-8195.

64 H. Feng, R. Cheng, X. Zhao, X. Duan and J. Li, A low-temperature method to produce highly reduced graphene oxide, Nature Communications, 2013, 4, 1537-1539.

65 C. Mattevi, G. Eda, S. Agnoli, S. Miller, K. A. Mkhoyan, O. Celik, D. Mastrogiovanni, G. Granozzi, E. Carfunkel and M. Chhowalla, Evolution of electrical, chemical, and structural properties of transparent and conducting chemically derived graphene thin films, Advanced Functional Materials, 2009, 19(16), 2577-2583.

66 C. Huang, C. Li and G. Shi, Graphene based catalysts, Energy \& Environmental Science, 2012, 5(10), 8848.

67 D. A. C. Brownson, D. K. Kampouris and C. E. Banks, An overview of graphene in energy production and storage applications, Journal of Power Sources, 2011, 196(11), 4873-4885.

68 X. Wang, H. You, F. Liu, M. Li, L. Wan, S. Li, Q. Li, Y. Xu, R. Tian, Z. Yu, D. Xiang and J. Cheng, Large-scale synthesis of few-layered graphene using CVD, Chemical Vapor Deposition, 2009, 15(1-3), 53-56.

69 Z. Chen, W. Ren, B. Liu, L. Gao, S. Pei, Z. S. Wu, J. Zhao and H. M. Cheng, Bulk growth of mono- to few-layer graphene on nickel particles by chemical vapor deposition from methane, Carbon, 2010, 48(12), 3543-3550.

70 Y. Shen and A. C. Lua, A facile method for the large-scale continuous synthesis of graphene sheets using a novel catalyst, Scientific Reports, 2013, 3, $1-6$.

71 C. Shan, H. Tang, T. Wong, L. He and S. T. Lee, Facile synthesis of a large quantity of graphene by chemical vapor deposition: An advanced catalyst carrier, Advanced Materials, 2012, 24(18), 2491-2495. 
72 S. Dayou, B. Vigolo, A. Desforges, J. Ghanbaja and A. R. Mohamed, High-rate synthesis of graphene by a lower cost chemical vapor deposition route, Journal of Nanoparticle Research, 2017, 19(10), 336.

73 X. Li, W. Cai, J. An, S. Kim, J. Nah, D. Yang, R. Piner, A. Velamakanni, I. Jung, E. Tutuc, S. K. Banerjee, L. Colombo and R. S. Ruoff, Large area synthesis of high quality and uniform graphene films on copper foils, Science, 2009, 324(5932), 1312-1314.

74 D. A. C. Brownson, S. A. Varey, F. Hussain, S. J. Haigh and C. E. Banks, Electrochemical properties of CVD grown pristine graphene: monolayer- vs. quasi-graphene, Nanoscale, 2014, 6(3), 1607-1621.

75 H. Sun, J. Xu, C. Wang, G. Ge, Y. Jia, J. Liu, F. Song and J. Wan, Synthesis of large-area monolayer and bilayer graphene using solid coronene by chemical vapor deposition, Carbon, 2016, 108, 356-362.

76 J. Jang, M. Son, S. Chung, K. Kim, C. Cho, B. H. Lee and M. Ham, Lowtemperature-grown continuous graphene films from benzene by chemical vapor deposition at ambient pressure, Scientific Reports, 2015, 5, 17955.

77 N. Pierard, A. Fonseca, J. F. Colomer, C. Bossuot, J. M. Benoit, G. Van Tendeloo, J. P. Pirard and J. B. Nagy, Ball milling effect on the structure of single-wall carbon nanotubes, Carbon, 2004, 42(8-9), 1691-1697.

78 H. Wakayama, J. Mizuno, Y. Fukushima, K. Nagano, T. Fukunaga and U. Mizutani, Structural defects in mechanically ground graphite, Carbon, 1999, 37(6), 947-952.

79 B. Alinejad and K. Mahmoodi, Synthesis of graphene nanoflakes by grinding natural graphite together with $\mathrm{NaCl}$ in a planetary ball mill, Functional Materials Letters, 2017, 10(04), 1750047.

80 V. Leon, M. Quintana, M. A. Herrero and J. L. G. Fierro, Few-layer graphenes from ball-milling of graphite with melamine, Chemical communication, 2011, 47, 10936-10938.

81 L. Liu, Z. Xiong, D. Hu, W. Guotao and P. Chen, Production of high quality single- or few-layered graphene by solid exfoliation of graphite in the presence of ammonia borane, Chemical Communication, 2013, 49(72), 7890-7892.

82 C. Knieke, A. Berger, M. Voigt, R. N. Klupp Taylor, J. Röhrl and W. Peukert, Scalable production of graphene sheets by mechanical delamination, Carbon, 2010, 48(11), 3196-3204.

83 J. A. Siddique, N. F. Attia and K. E. Geckeler, Polymer nanoparticles as a tool for the exfoliation of graphene sheets, Materials Letters, 2015, 158, 186-189.

84 M. Mao, S. Chen, P. He, H. Zhang and L. Hongtao, Facile and economical mass production of graphene dispersions and flake, Journal of Materials Chemistry A, 2014, 2, 4132-4135.

85 T. Lin, J. Chen, H. Bi, D. Wan, F. Huang, X. Xie and M. Jiang, Facile and economical exfoliation of graphite for mass production of high-quality graphene sheets, Journal of Materials Chemistry A, 2013, 1(3), 500-504.

86 R. Aparna, N. Sivakumar, A. Balakrishnan, A. S. Nair, S. V Nair, R. Aparna, N. Sivakumar, A. Balakrishnan and A. S. Nair, An effective route to produce few-layer graphene using combinatorial ball milling and strong aqueous exfoliants, Journal of Renewable and Sustainable Energy, 2013, 5, 033123.

87 S. Deng, X. dong Qi, Y. ling Zhu, H. ju Zhou, F. Chen and Q. Fu, A facile way to large-scale production of few-layered graphene via planetary ball mill, Chinese Journal of Polymer Science (English Edition), 2016, 34(10), 12701280. 
88 G.-N. Kim, J.-H. Kim, B.-S. Kim, H.-M. Jeong and S.-C. Huh, Study on the Thermal Conductivity Characteristics of Graphene Prepared by the Planetary Ball Mill, Metals, 2016, 6(10), 234.

89 W. Zhao, M. Fang, F. Wu, H. Wu, L. Wang and G. Chen, Preparation of graphene by exfoliation of graphite using wet ball milling, Journal of Materials Chemistry, 2010, 20, 5817-5819.

90 A. D. Rud, A. E. Perekos, V. M. Ogenko, A. P. Shpak, V. N. Uvarov, K. V. Chuistov, A. M. Lakhnik, V. Z. Voynash and L. I. Ivaschuk, Different states of carbon produced by high-energy plasmochemistry synthesis, Journal of NonCrystalline Solids, 2007, 353(32-40), 3650-3654.

91 H. Suematsu, C. Minami, R. Kobayashi, Y. Kinemuchi, T. Hirata, R. Hatakeyama, S. C. Yang, W. Jiang and K. Yatsui, Preparation of Fullerene by Pulsed Wire Discharge, Japanese Journal of Applied Physics, Part 2: Letters, 2003, 42(8 B), 12-16.

92 R. Kobayashi, S. Nishimura, T. Suzuki, H. Suematsu, W. Jiang and K. Yatsui, Synthesis of single-walled carbon nanotubes by pulsed wire discharge, Japanese Journal of Applied Physics, Part 1: Regular Papers and Short Notes and Review Papers, 2005, 44(1 B), 742-744.

93 G. P. Singh, B. N. Flanders and C. M. Sorensen, One-step synthesis of graphene via catalyst-free gas-phase hydrocarbon detonation, Nanotechnology, 2013, 24, 245602.

94 X. Gao, C. Xu, H. Yin, X. Wang, Q. Song and P. Chen, Preparation of graphene by electrical explosion of graphite sticks, Nanoscale, 2017, 9(30), 10639-10646.

95 H. Yin, P. Chen, C. Xu, X. Gao, Q. Zhou, Y. Zhao and L. Qu, Shock-wave synthesis of multilayer graphene and nitrogen-doped graphene materials from carbonate, Carbon, 2015, 94, 928-935.

96 P. Chen, C. Xu, H. Yin, X. Gao and L. Qu, Shock induced conversion of carbon dioxide to few layer graphene, Carbon, 2017, 115, 471-476.

97 M. Choucair, P. Thordarson and J. A. Stride, Gram-scale production of graphene based on solvothermal synthesis and sonication., Nature nanotechnology, 2009, 4(1), 30-33.

98 X. Xin, G. Xu, T. Zhao, Y. Zhu, X. Shi and H. Gong, Dispersing Carbon Nanotubes in Aqueous Solutions by a Starlike Block Copolymer, Journal of Physical Chemistry C, 2008, 112, 16377-16384.

99 J. N. Coleman, Liquid-phase exfoliation of nanotubes and graphene, Advanced Functional Materials, 2009, 19(23), 3680-3695.

100 S. D. Bergin, V. Nicolosi, P. V. Streich, S. Giordani, Z. Sun, A. H. Windle, P. Ryan, N. P. P. Niraj, Z. T. T. Wang, L. Carpenter, W. J. Blau, J. J. Boland, J. P. Hamilton and J. N. Coleman, Towards solutions of single-walled carbon nanotubes in common solvents, Advanced Materials, 2008, 20(10), 1876-1881.

101 J. N. Coleman, Liquid exfoliation of defect-free graphene, Accounts of Chemical Research, 2013, 46(1), 14-22.

102 U. Khan, A. O'Neill, M. Lotya, S. De and J. N. Coleman, High-concentration solvent exfoliation of graphene, Small, 2010, 6(7), 864-871.

103 Y. Hernandez, V. Nicolosi, M. Lotya, F. Blighe, Z. Sun, S. De, I. T. McGovern, B. Holland, M. Byrne, Y. Gunko, J. Boland, P. Niraj, G. Duesberg, S. Krishnamurti, R. Goodhue, J. Hutchison, V. Scardaci, a. C. Ferrari and J. N. Coleman, High yield production of graphene by liquid phase exfoliation of graphite, Nature Nanotechnology, 2008, 3(9), 563-568. 
104 X. Zhang, A. C. Coleman, N. Katsonis, W. R. Browne, B. J. van Wees and B. L. Feringa, Dispersion of graphene in ethanol using a simple solvent exchange method, Chemical Communications, 2010, 46(40), 7539.

105 A. O'Neill, U. Khan, P. N. Nirmalraj, J. Boland and J. N. Coleman, Graphene dispersion and exfoliation in low boiling point solvents, Journal of Physical Chemistry C, 2011, 115(13), 5422-5428.

106 M. Lotya, Y. Hernandez, P. J. King, R. J. Smith, V. Nicolosi, L. S. Karlsson, M. Blighe, S. De, Z. Wang, I. T. Mcgovern, G. S. Duesberg, J. N. Coleman and F. M. Blighe, Liquid Phase Production of Graphene by Exfoliation of Graphite in Surfactant / Water Solutions, Journal of the American Chemical Society, 2009, 131(11), 3611-3620.

107 A. A. Green and M. C. Hersam, Solution phase production of graphene with controlled thickness via density differentiation, Nano Letters, 2009, 9(12), 4031-4036.

108 R. Hao, W. Qian, L. Zhang and Y. Hou, Aqueous dispersions of TCNQ-anionstabilized graphene sheets, Chemical Communication, 2008, 6576-6578.

109 S. Vadukumpully, J. Paul and S. Valiyaveettil, Cationic surfactant mediated exfoliation of graphite into graphene flakes, Carbon, 2009, 47(14), 3288-3294.

110 V. Štengl, Preparation of graphene by using an intense cavitation field in a pressurized ultrasonic reactor, Chemistry - A European Journal, 2012, 18(44), 14047-14054.

111 T. J. Mason, Ultrasound in synthetic organic chemistry, Chemical Society Reviews, 1997, 26(6), 443-451.

112 R. Narayan and S. O. Kim, Surfactant mediated liquid phase exfoliation of graphene, Nano Convergence, 2015, 2(1), 20.

113 H. Beneš, R. K. Donato, P. Ecorchard, D. Popelková, E. Pavlová, D. Schelonka, O. Pop-Georgievski, H. S. Schrekker and V. Štengl, Direct delamination of graphite ore into defect-free graphene using a biphasic solvent system under pressurized ultrasound, RSC Advances, 2016, 6(8), 6008-6015.

114 P.-C. Lin, Y.-R. Chen, K.-T. Hsu, T.-N. Lin, K.-L. Tung, J.-L. Shen and W.-R. Liu, Nano-sized graphene flakes: Insights from experimental synthesis and first principles calculations, Physical Chemistry Chemical Physics, 2016, 1-8.

115 Y. Shao, J. Wang, M. Engelhard, C. Wang and Y. Lin, Facile and controllable electrochemical reduction of graphene oxide and its applications, J. Mater. Chem., 2010, 20(4), 743-748.

116 G. M. Morales, P. Schifani, G. Ellis, C. Ballesteros, G. Martínez, C. Barbero and H. J. Salavagione, High-quality few layer graphene produced by electrochemical intercalation and microwave-assisted expansion of graphite, Carbon, 2011, 49(8), 2809-2816.

117 M. Alanyalioğlu, J. J. Segura, J. Oró-Sol and N. Casañ-Pastor, The synthesis of graphene sheets with controlled thickness and order using surfactant-assisted electrochemical processes, Carbon, 2012, 50(1), 142-152.

118 S. A. Sharief, R. A. Susantyoko, M. Alhashem and S. Almheiri, Synthesis of few-layer graphene-like sheets from carbon-based powders via electrochemical exfoliation, using carbon black as an example, Journal of Materials Science, 2017, 52(18), 11004-11013.

119 M. Alfè, V. Gargiulo, R. Di Capua, F. Chiarella, J.-N. Rouzaud, A. Vergara and A. Ciajolo, Wet chemical method for making graphene-like films from carbon black., ACS applied materials \& interfaces, 2012, 4(9), 4491-8.

120 K. Parvez, Z. Wu, R. Li, X. Liu, R. Graf and X. Feng, Exfoliation of Graphite 
into Graphene in Aqueous Solutions of Inorganic Salts, Journal of the American Chemical Society, 2014, 136, 6083-6091.

121 S. Yang, S. Brüller, Z. S. Wu, Z. Liu, K. Parvez, R. Dong, F. Richard, P. Samorì, X. Feng and K. Müllen, Organic Radical-Assisted Electrochemical Exfoliation for the Scalable Production of High-Quality Graphene, Journal of the American Chemical Society, 2015, 137(43), 13927-13932.

122 S. Sathyamoorthi, V. Suryanarayanan and D. Velayutham, Electrochemical exfoliation and in situ carboxylic functionalization of graphite in non-fluoro ionic liquid for supercapacitor application, Journal of Solid State Electrochemistry, 2014, 18(10), 2789-2796.

123 Z. Liu, Z. S. Wu, S. Yang, R. Dong, X. Feng and K. Müllen, Ultraflexible InPlane Micro-Supercapacitors by Direct Printing of Solution-Processable Electrochemically Exfoliated Graphene, Advanced Materials, 2016, 28(11), 2217-2222.

124 Y. Yang, F. Lu, Z. Zhou, W. Song, Q. Chen and X. Ji, Electrochimica Acta Electrochemically cathodic exfoliation of graphene sheets in room temperature ionic liquids N-butyl, methylpyrrolidinium bis ( trifluoromethylsulfonyl ) imide and their electrochemical properties, Electrochimica Acta, 2013, 113, 916.

125 M. Pumera, C. Hong, A. Wong, A. Yong, S. Eng and A. Bonanni, Graphene and its electrochemistry - an update, Chem Soc Rev, 2016, 45(9), 2458-2493.

126 J. Wang, K. K. Manga, Q. Bao and K. P. Loh, High-Yield Synthesis of FewLayer Graphene Flakes through Electrochemical Expansion of Graphite in Propylene Carbonate Electrolyte, Journal of the American Chemical Society, 2011, 133, 8888-8891.

127 W. Wu, C. Zhang and S. Hou, Electrochemical exfoliation of graphene and graphene-analogous 2D nanosheets, Journal of Materials Science, 2017, 52(18), 10649-10660.

128 A. M. Abdelkader, A. J. Cooper, R. A. W. Dryfe and I. A. Kinloch, How to get between the sheets: A review of recent works on the electrochemical exfoliation of graphene materials from bulk graphite, Nanoscale, 2015, 7(16), 6944-6956.

129 P. Yu, S. E. Lowe, G. P. Simon and Y. L. Zhong, Electrochemical exfoliation of graphite and production of functional graphene, Current Opinion in Colloid and Interface Science, 2015, 20(5-6), 329-338.

130 W. Dai, C. Y. Chung, F. E. Alam, T. T. Hung, H. Sun, Q. Wei, C. Te Lin, S. K. Chen and T. S. Chin, Superior field emission performance of graphene/carbon nanofilament hybrids synthesized by electrochemical self-exfoliation, Materials Letters, 2017, 205, 223-225.

131 D. B. Shinde, J. Brenker, C. D. Easton, R. F. Tabor, A. Neild and M. Majumder, Shear Assisted Electrochemical Exfoliation of Graphite to Graphene, Langmuir, 2016, 32(14), 3552-3559.

132 C.-W. Chen, Z.-T. Liu, Y.-Z. Zhang, J.-S. Ye and C.-L. Lee, Sonoelectrochemical intercalation and exfoliation for the preparation of defective graphene sheets and their application as nonenzymatic $\mathrm{H} 2 \mathrm{O} 2$ sensors and oxygen reduction catalysts, $R S C A d v$., 2015, 5(28), 21988-21998.

133 U. Khan, H. Porwal, A. O’Neill, K. Nawaz, P. May and J. N. Coleman, Solvent-exfoliated graphene at extremely high concentration, Langmuir, 2011, 27(15), 9077-9082.

134 M. Lotya, P. J. King, U. Khan, S. De and J. N. Coleman, High-Concentration, 
Surfactant- Stabilized Graphene Dispersions, ACS Nano, 2010, 4(6), 31553162.

135 E. Varrla, K. R. Paton, C. Backes, A. Harvey, R. J. Smith, J. McCauley and J. N. Coleman, Turbulence-assisted shear exfoliation of graphene using household detergent and a kitchen blender, Nanoscale, 2014, 6(20), 1181011819.

136 K. R. Paton, E. Varrla, C. Backes, R. J. Smith, U. Khan, A. O’Neill, C. Boland, M. Lotya, O. M. Istrate, P. King, T. Higgins, S. Barwich, P. May, P.

Puczkarski, I. Ahmed, M. Moebius, H. Pettersson, E. Long, J. Coelho, S. E. O’Brien, E. K. McGuire, B. M. Sanchez, G. S. Duesberg, N. McEvoy, T. J. Pennycook, C. Downing, A. Crossley, V. Nicolosi and J. N. Coleman, Scalable production of large quantities of defect-free few-layer graphene by shear exfoliation in liquids, Nature Materials, 2014, 13(6), 624-630.

137 R. Wengeler and H. Nirschl, Turbulent hydrodynamic stress induced dispersion and fragmentation of nanoscale agglomerates, Journal of Colloid and Interface Science, 2007, 306(2), 262-273.

138 X. Chen, J. F. Dobson and C. L. Raston, Vortex fluidic exfoliation of graphite and boron nitride, Chemical Communications, 2012, 48(31), 3703.

139 E. T. Bjerglund, M. E. P. Kristensen, S. Stambula, G. A. Botton, S. U. Pedersen and K. Daasbjerg, Efficient Graphene Production by Combined Bipolar Electrochemical Intercalation and High-Shear Exfoliation, ACS Omega, 2017, 2(10), 6492-6499.

140 M. Yi and Z. Shen, A review on mechanical exfoliation for the scalable production of graphene, J. Mater. Chem. A, 2015, 3(22), 11700-11715.

141 T. S. Tran, S. J. Park, S. S. Yoo, T.-R. Lee and T. Kim, High shear-induced exfoliation of graphite into high quality graphene by Taylor-Couette flow, RSC Adv., 2016, 6(15), 12003-12008.

142 D. A. Simon, E. Bischoff, G. G. Buonocore, P. Cerruti, M. G. Raucci, H. Xia, H. S. Schrekker, M. Lavorgna, L. Ambrosio and R. S. Mauler, Graphene-based masterbatch obtained via modified polyvinyl alcohol liquid-shear exfoliation and its application in enhanced polymer composites, Materials \& Design, 2017, 134, 103-110. 